\title{
Impact of $\mathrm{Mg}^{2+}$ and $\mathrm{Zn}^{2+}$ Addition on the Structural, Morphological, Physicochemical, Dielectric and Biological Properties of Hydroxyapatite
}

Anandhan Narayanasamy ( $\nabla$ anandhan_kn@rediffmail.com )

Alagappa University https://orcid.org/0000-0001-6783-6337

Panneerselvam Ramaswamy

Alagappa University Faculty of Science

Poonguzhali Ramaswamy

Trinity College for Women

Amali Roselin Arockiam

Alagappa University Faculty of Science

Joseph Panneerdoss Issac

Alagappa University Faculty of Science

\section{Ganesan Karuppannan Periannan}

Alagappa University Faculty of Science

\section{Sugumar Vasudevan}

Alagappa University Faculty of Science

\section{Research Article}

Keywords: Hydroxyapatite, Dielectric, Hardness, XPS, VSM, Antibiofilm

Posted Date: October 6th, 2021

DOI: https://doi.org/10.21203/rs.3.rs-942141/v1

License: (c) (i) This work is licensed under a Creative Commons Attribution 4.0 International License. Read Full License 


\section{Abstract}

In the present work, the wet-chemical precipitation technique is employed to prepare Zinc/Magnesium doped hydroxyapatite $\left(H A_{P}\right)$. In doped $H A_{p}$, the X-ray diffraction peak shifts to a higher angle because of the contraction of the lattice parameters along $a$ - axis. The Raman peaks at $519,440,1464 \mathrm{~cm}^{-1}$ indicate the presence of $\mathrm{Mg}, \mathrm{Zn}$ and $\mathrm{CO}_{3}{ }^{2-}$ in doped $\mathrm{HA}_{\mathrm{p}}$ respectively. The Field Emission Scanning Electron Microscopy (FESEM) measures the grain size of pure, $5 \% \mathrm{Zn}$ and $5 \% \mathrm{Mg}$ doped $\mathrm{HA}_{\mathrm{p}}$, as 275,510 , and $251 \mathrm{~nm}$ respectively. Transmission Electron Microscopy (TEM) confirmed the morphological change in $\mathrm{HA}$. The X-ray photoelectron spectroscopy (XPS) identifies the presence of $\mathrm{Mg}^{2+}$ and $\mathrm{Zn}^{2+}$ in doped $\mathrm{HA}_{\mathrm{p}}$. The dopant elevates the hardness and dielectric constant, so the strength and the bone growth of $\mathrm{HA}_{\mathrm{p}}$ increases. All the doped samples show excellent antibacterial, antifungal and antibiofilm activities than the pure $H A_{p}$.

\section{Introduction}

Hydroxyapatite $\left[\mathrm{Ca}_{10}\left(\mathrm{PO}_{4}\right)_{6}(\mathrm{OH})_{2}\right]\left(\mathrm{HA}_{\mathrm{P}}\right)$ is a biomaterial used to exchange part of a living system and giving contact to the living tissue. Bioceramic materials play a vital role in restoring and regenerating the tissues in the human body. Nano hydroxyapatite is playing important role in the hip joint, bone and dental replacements. Also, when nano biomaterial is implanted in the human body it shows outstanding osteoconductivity and osteoinduction properties. Nano $\mathrm{HA}_{p}$ delivers drugs effectively to treat bone infections [1]. Hydroxyapatite is osteoconductive but it is not osteoinductive and inherently possesses brittle nature. Further, the improvement on physiochemical and biological characteristics of $\mathrm{HA}_{\mathrm{p}}$ is analysed by the researchers to date [2]. The presence of zinc in biological tissues induces bone mineralization and promotes pathological calcification. The $\mathrm{Zn}$ in the human body also plays a significant factor in the maintenance of membrane structure, function, protein synthesis, DNA synthesis, mitosis and cell proliferation [3]. Recently the cytotoxic and antibacterial activity of Zinc doped $\mathrm{HA}_{\mathrm{p}}$ has been reported [4]. The structure of $\mathrm{HA}_{p}$ accepts the substitution of ions without any change in its hexagonal shape. But the substitution ions change the lattice parameter, crystallinity and morphology of $\mathrm{HA}_{\mathrm{p}}$. The nature of the substitution ions plays an important factor in the bone curing method, the addition of $\mathrm{Zn}$ enhances the bioactivity and antibacterial properties of pure $\mathrm{HA}$. The $\mathrm{Zn}$ incorporated $\mathrm{HA}$ is more useful in orthopedics because it increases bone formation and reduces bone resorption. Substituting a high quantity of $\mathrm{Zn}$ with pure $\mathrm{HA}_{\mathrm{p}}$ may cause a cytotoxic effect, so a low amount of $\mathrm{Zn}$ to be added with $\mathrm{HA}_{\mathrm{p}}$ [5]. Suchanek et al. and Webster et al. found that the addition of ions changes the biophysical and chemical nature of $\mathrm{HA}_{\mathrm{p}}$ ceramics [6 and 7]. Venkatasubbu group showed that the increase in the concentration of zinc in $H A_{p}$ causes a decrease in crystallite size [8]. Wang et al. noticed the morphological change in $\mathrm{HA}_{p}$ from the hexagonal to spherical shape due to the addition of zinc [9]. Magnesium (Mg) in bone has biocompatibility with living cells and stimulates osteoblast proliferation. The lack of $\mathrm{Mg}$ creates bone loss. Magnesium incorporated $\mathrm{HA}_{\mathrm{p}}$ has no cytotoxic effects [10]. Kanasan and his group observed that the increase in $\mathrm{Mg}$ content in $\mathrm{HA}_{p}$ elevates the microhardness [11]. Salam and his group noticed that the increase in $\mathrm{Mg}$ content in $H A_{p}$ increases the electrical conduction and hence bioactivity of $H A_{p}$ increases [12]. Even though some of the researchers have studied the Zinc and Magnesium doped $H A_{p}$ they used a bulk amount of dopant. They did not heat the doped $\mathrm{HA}_{\mathrm{p}}$ to a higher temperature, and also did not concentrate much on the studies like microhardness, magnetic behavior and antibiofilm activity. Hence, the present investigation turned to 
synthesize $\mathrm{Zn}^{2+}$ and $\mathrm{Mg}^{2+}$ doped $\mathrm{HA}_{\mathrm{P}}$ nanostructures for various concentrations by using a simple wet chemical precipitation method. The characterizations of structural, morphological, biological, mechanical, electrical, and magnetic properties of pure and incorporated $\mathrm{HA}_{\mathrm{p}}$ are analyzed in a detailed manner.

\section{Experimental Procedure}

\subsection{Preparation of Pure, $\mathrm{Zn}$ and $\mathrm{Mg}$ doped $\mathrm{HA}$}

In this investigation, pure and 1,3 , and 5 mole percentages of zinc and magnesium separately added nano-HA samples were prepared by employing the wet-chemical precipitation method. Table 1 shows the raw materials used for the preparation of pure and doped $\mathrm{HA}$. The calcium chloride dihydrate $\left(\mathrm{CaCl}_{2} \cdot 2 \mathrm{H}_{2} \mathrm{O}\right)$ and di-sodium hydrogen phosphate $\left(\mathrm{Na}_{2} \mathrm{HPO}_{4}\right)$ were used as $\mathrm{Ca}^{2+}$ and $\mathrm{PO}_{4}{ }^{3-}$ precursors respectively. The dopant was mixed with the $\mathrm{CaCl}_{2} \cdot 2 \mathrm{H}_{2} \mathrm{O}$ solution. The $\mathrm{pH}$ of $\mathrm{Ca}^{2+}$ and $\mathrm{PO}_{4}{ }^{3-}$ precursor solutions was maintained at 11 by using 1 mole of $\mathrm{NaOH}$. While $\mathrm{Ca}^{2+}$ precursor was maintaining at $60^{\circ} \mathrm{C}$ and stirring at the rate of $600 \mathrm{rpm}^{2} \mathrm{PO}_{4}{ }^{3-}$ precursor was added drop by drop into it. After washing and filtering the obtained yield was heat treated at $900^{\circ} \mathrm{C}$ for $2 \mathrm{~h}$. All the chemicals used for the preparation of samples are from Merck India.

Table 1

$\mathrm{Ca} / \mathrm{P}$ ratio and raw materials used for sample preparation.

\begin{tabular}{|c|c|c|c|c|c|c|c|c|}
\hline \multirow[t]{2}{*}{ Sample } & \multicolumn{2}{|c|}{$\mathrm{CaCl}_{2} \cdot 2 \mathrm{H}_{2} \mathrm{O}$} & \multicolumn{2}{|c|}{$\mathrm{Na}_{2} \mathrm{HPO}_{4}$} & \multicolumn{2}{|c|}{ Dopant } & \multirow[t]{2}{*}{$\mathrm{Ca} / \mathrm{P}$} & \multirow[t]{2}{*}{$(\mathrm{Ca}+$ dopant $) / \mathrm{P}$} \\
\hline & gram & Mole & gram & Mole & gram & Mole & & \\
\hline Pure $H A_{P}$ & 7.351 & 1 & 4.258 & 0.6 & NA & NA & 1.67 & 1.67 \\
\hline $1 \% \mathrm{ZnHA}_{\mathrm{P}}$ & 7.277 & 0.99 & 4.258 & 0.6 & 0.066 & 0.01 & 1.65 & 1.67 \\
\hline $3 \% \mathrm{ZnHA}_{\mathrm{P}}$ & 7.130 & 0.97 & 4.258 & 0.6 & 0.198 & 0.03 & 1.61 & 1.67 \\
\hline $5 \% \mathrm{ZnHA}_{\mathrm{P}}$ & 6.983 & 0.95 & 4.258 & 0.6 & 0.331 & 0.05 & 1.58 & 1.67 \\
\hline $1 \% \mathrm{MgHA}_{\mathrm{P}}$ & 7.277 & 0.99 & 4.258 & 0.6 & 0.128 & 0.01 & 1.65 & 1.67 \\
\hline $3 \% \mathrm{MgHA}_{\mathrm{P}}$ & 7.130 & 0.97 & 4.258 & 0.6 & 0.385 & 0.03 & 1.61 & 1.67 \\
\hline $5 \% \mathrm{MgHA}_{P}$ & 6.983 & 0.95 & 4.258 & 0.6 & 0.641 & 0.05 & 1.58 & 1.67 \\
\hline
\end{tabular}

\subsection{Characterization Techniques}

X-ray diffraction (XRD) pattern was obtained for the prepared samples by employing the powder X-ray diffractometer PAN analytical X' Pert Pro, Carbatuib, WA and USA (with Cu-Ka radiation, $\lambda=1.54060 \AA$ ) at $40 \mathrm{kV}$ and $30 \mathrm{~mA}$. FT-IR spectra were obtained with a Magna IR spectrometer 550 Nicolet over the region $4000-400$ $\mathrm{cm}^{-1}$. The morphology of the samples was analyzed by using FE-SEM analysis with EDX and it was carried out by using FEI Quanta 250 and the CZECH Republic respectively. The Micro Raman spectra of the prepared samples were obtained using a micro-Raman spectrometer and it was irradiated with a wavelength of 514.5 
nm (Princeton Equipment Model: Acton SP 2500). The morphology of the samples was analysed by using TEM-Technai and G220 Twin FEI Instrument (Czech Republic). PHI VersaProbe Spectrometer was used for XPS analysis. The capacitance and the dielectric losses were estimated using the LCRZ-model TH2816A instrument. Shimadzu Model: HMV-2T was used to study the microhardness of the prepared samples. The antibacterial and antifungal activity was carried out by employing disc diffusion and well diffusion methods respectively. The antibiofilm activity was carried out against bacterial stains.

\section{Results And Discussion}

\subsection{X-ray Diffraction (XRD) Analysis}

Figures $\mathrm{S} 1$ and $\mathrm{S} 2$ show the XRD patterns of pure and $\mathrm{ZnHA}_{p}$, pure and $\mathrm{MgHA} \mathrm{A}_{p}$ samples respectively (Refer supplementary). Figure 1 illustrates the XRD patterns of the pure, $5 \% \mathrm{Zn}$, and $5 \% \mathrm{Mg}$-doped HAp. From the XRD pattern, the calculated lattice constants ( $a$ and $c$ ), unit cell volume $(V)$ are in Table 2 and the crystallite size (D), microstrain $(\varepsilon)$, dislocation density $(\rho)$, the fraction of crystallinity $(\mathrm{Xc})$ and specific surface area $(\mathrm{S})$ are in Table $3[13,14]$. All the XRD results are in good accord with the joint committee for powder diffraction standard

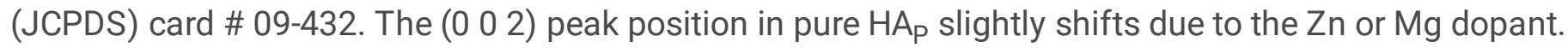
Lattice parameters $a$ and $b$ decrease while the $c$ almost remains the same due to the substitution ions, hence the (210) and (300) peak positions shift to higher angles [15]. In $\mathrm{HA}_{\mathrm{p}}$ structure, $\mathrm{Zn}^{2+} \mathrm{or} \mathrm{Mg}^{2+}$ can occupy any one of the following $\mathrm{Ca}(\mathrm{I}), \mathrm{Ca}(\mathrm{II}), \mathrm{P}$ and $\mathrm{OH}$ positions. The radius of $\mathrm{Ca}^{2+}, \mathrm{P}^{5-}, \mathrm{Zn}^{2+}$ and $\mathrm{Mg}^{2+}$ ions are 0.099 , $0.031,0.074$, and $0.065 \mathrm{~nm}$ respectively. The $\mathrm{Ca}(\mathrm{I})$ and $\mathrm{P}^{5-}$ atoms form an octahedral structure with their $\mathrm{O}^{2-}$ atoms. But $\mathrm{Ca}$ (II) atoms form a tetrahedral structure with $\mathrm{O}^{2-}$ atoms. To form a tetrahedral structure less energy is required than to form an octahedral structure. However, the difference in ionic radius and charge of $\mathrm{Zn}^{2+}$ and $\mathrm{Mg}^{2+}$ ions are more likely to replace $\mathrm{Ca}^{2+}$ ions. The $\mathrm{Zn}^{2+}$ and $\mathrm{Mg}^{2+}$ ions prefer Ca (II) ion to replace, due to lesser energy required in the formation of tetrahedral structure [16]. The ionic radius of $\mathrm{Ca}^{2+}$ is greater than $\mathrm{Zn}^{2+}$ and $\mathrm{Mg}^{2+}$. Therefore, the crystallite size decreases with an increase in dopant concentration. This result is consistent with the previous reports $[8,17,18]$. The mismatch of the ionic radius of $\mathrm{Zn}^{2+}$ and $\mathrm{Mg}^{2+}$ with the $\mathrm{Ca}^{2+}$ creates a defect in the crystal array. Hence from the calculated values, it is found that, when the dopant concentration increased, the surface area, dislocation density and strain of the prepared samples are increasing whereas the crystallite size decreases. If the substitution ion replaced the $\mathrm{OH}$ ion in $\mathrm{HAp}$, the crystallite size might get increased; the decrease in crystallite size, confirms that the dopant ion replaced $\mathrm{Ca}^{2+}$. These results are in good accord with Miculescu et al.[19]. 
Table 2

Calculated lattice constants $a, c$ and unit cell volume of the samples.

\begin{tabular}{|llll|}
\hline Sample & Parameter $a(\AA)$ & Parameter $c(\AA)$ & Unit cell volume $(\AA))^{3}$ \\
\hline Pure HA & 9.541 & 6.872 & 541.816 \\
\hline $1 \% \mathrm{ZnHA} P$ & 9.51 & 6.828 & 534.907 \\
\hline$\% \mathrm{ZnHA}_{P}$ & 9.504 & 6.817 & 533.257 \\
\hline $5 \% \mathrm{ZnHA} P$ & 9.501 & 6.812 & 532.529 \\
\hline $1 \% \mathrm{MgHA}$ & 9.616 & 6.85 & 547.544 \\
\hline $3 \% \mathrm{MgHA}$ & 9.52 & 6.828 & 535.917 \\
\hline $5 \% \mathrm{MgHA}$ & 9.474 & 6.813 & 529.585 \\
\hline
\end{tabular}

Table 3

The reported values of crystallite size (D), dislocation density $(\rho)$, strain $(\varepsilon)$,

\begin{tabular}{|c|c|c|c|c|c|}
\hline Sample & $\begin{array}{l}\text { Crystallite } \\
\text { Size (nm) }\end{array}$ & $\begin{array}{l}\text { Dislocation Density } \times \\
10^{15}\left(\text { lines } / \mathrm{m}^{2}\right)\end{array}$ & $\begin{array}{l}\text { Strain } \times 10^{-4} \\
\left(\text { line }{ }^{-2} \cdot m^{-4}\right)\end{array}$ & $\begin{array}{l}\text { Surface Area } \times \\
10^{11} \mathrm{~m}^{2} / \mathrm{g}\end{array}$ & $\begin{array}{l}\text { Fraction of } \\
\text { Crystallinity (Xc) }\end{array}$ \\
\hline $\begin{array}{l}\text { Pure } \\
H A_{p}\end{array}$ & 65.39 & 0.259 & 1.096 & 2.903 & 7.702 \\
\hline $1 \% \mathrm{ZnH}_{\mathrm{P}}$ & 62.85 & 0.276 & 1.548 & 3.021 & 6.851 \\
\hline $3 \% \mathrm{ZnH}_{\mathrm{P}}$ & 56.87 & 0.309 & 2.257 & 3.338 & 3.813 \\
\hline $5 \% \mathrm{ZnH}_{\mathrm{P}}$ & 53.83 & 0.345 & 2.603 & 3.527 & 2.418 \\
\hline $1 \% \mathrm{MgH}_{\mathrm{P}}$ & 61.4 & 0.265 & 2.113 & 3.092 & 5.435 \\
\hline $3 \% \mathrm{MgH}_{\mathrm{P}}$ & 55.86 & 0.321 & 2.703 & 3.399 & 4.299 \\
\hline $5 \% \mathrm{MgH}_{\mathrm{P}}$ & 52.35 & 0.382 & 2.854 & 3.626 & 3.677 \\
\hline
\end{tabular}

surface area (S) and the fraction of crystallinity (Xc) for pure, Zn and Mg-doped HA .

\subsection{FT-IR Analysis}

The supplementary Figs. S3 and S4 illustrate the Fourier Transform infrared (FTIR) spectra for the prepared samples. Figure 2 illustrates the FTIR spectra of pure, $5 \% \mathrm{Zn}$ and $5 \% \mathrm{Mg}$ doped HAp. Table 4 depicts the FT-IR vibrational assignment of pure, $\mathrm{Zn}$ and $\mathrm{Mg}$ doped $\mathrm{HA}_{\mathrm{p}}$. The presence of $\mathrm{OH}^{-}$vibrations and $\mathrm{v}_{1}$ to $\mathrm{v}_{4}$ vibrations of $\mathrm{PO}_{4}{ }^{3-}$ in all the FT-IR spectra confirm the hydroxyapatite structure. The FT-IR spectra of $\mathrm{Zn} / \mathrm{Mg}$ doped samples are similar to the pure $\mathrm{HA}_{\mathrm{p}}$, but the intensity of the peak at $563 \mathrm{~cm}^{-1}$ slightly decreases with an increase in dopant concentration. The FT-IR bands at 1590 and $1418 \mathrm{~cm}^{-1}$ represent the carbonate in the samples. The presence of $\mathrm{CO}_{3}{ }^{2-}$ in the samples is due to $\mathrm{CO}_{2}$ in the air mixed with water during the preparation 
of $\mathrm{HA}_{\mathrm{P}}$ [20]. The bone structure consists of carbonate, so the presence of $\mathrm{CO}_{3}{ }^{2-}$ increases the bioactivity of the $H A_{p}$. The intensity of the carbonate peak decreases with the increase of concentration of $Z n$ in $H A_{p}$ whereas the intensity of the carbonate peak increases with the increase of concentration of $\mathrm{Mg}$ in $\mathrm{HA}_{\mathrm{p}}$. The peaks related to the $\mathrm{PO}_{4}{ }^{3-}$ and $\mathrm{OH}^{-}$become broad while raising the concentration of both $\mathrm{Zn}^{2+}$ and $\mathrm{Mg}^{2+}$ and it indicates the decrease in crystallinity of the $\mathrm{HA}_{\mathrm{P}}$ as obtained in XRD. Table 4 represents the $\mathrm{PO}_{4}{ }^{3-}, \mathrm{OH}^{-}$and $\mathrm{CO}_{3}{ }^{2-}$ vibrational assignment. There is no vibrational indication for $\mathrm{Zn}$ and $\mathrm{Mg}$ in FT-IR spectra.

Table 4

FT-IR vibrational bands assigned to pure, $\mathrm{Zn}$ and $\mathrm{Mg}$ doped $\mathrm{HA}$.

\begin{tabular}{|c|c|c|c|c|c|c|c|c|}
\hline \multirow[t]{2}{*}{$\begin{array}{l}\text { Pure } \\
\text { HAp }\end{array}$} & \multicolumn{3}{|c|}{ Zinc doped $H A_{p}$} & \multicolumn{3}{|c|}{$\begin{array}{l}\text { Magnesium doped } \\
\mathrm{HA} \mathrm{A}_{\mathrm{p}}\end{array}$} & \multirow[t]{2}{*}{ Assignment $\mathrm{cm}^{-1}$} & \multirow[t]{2}{*}{ Reference } \\
\hline & $1 \%$ & $3 \%$ & $5 \%$ & $1 \%$ & $3 \%$ & $5 \%$ & & \\
\hline 3574 & 3561 & 3566 & 3565 & 3571 & 3573 & 3573 & $\mathrm{OH}^{-}$Stretching & 15 \\
\hline 1590 & 1587 & 1588 & 1588 & 1578 & 1579 & 1579 & Carbonate ions $\left(\mathrm{CO}_{3}{ }^{2-}\right)$ & 20 \\
\hline 1418 & 1416 & 1422 & 1422 & 1416 & 1410 & 1424 & Carbonate ions $\left(\mathrm{CO}_{3}{ }^{2-}\right)$ & 2 \\
\hline 1090 & 1089 & 1091 & 1086 & 1088 & 1087 & 1090 & $\begin{array}{l}\mathrm{U}_{3} \text { Asymmetric stretching of } \mathrm{P}-\mathrm{O} \\
\text { in } \mathrm{PO}_{4}{ }^{3-}\end{array}$ & 8 \\
\hline 1040 & 1042 & 1043 & 1041 & 1047 & 1047 & 1047 & $\begin{array}{l}\mathrm{U}_{3} \text { Asymmetric stretching of } \mathrm{P}-\mathrm{O} \\
\text { in } \mathrm{PO}_{4}{ }^{3-}\end{array}$ & 15 \\
\hline 961 & 955 & 958 & 959 & 978 & 965 & 964 & $\begin{array}{l}\mathrm{U}_{1} \text { Symmetric stretching mode } \\
\text { of } \mathrm{P}-\mathrm{O} \text { in } \mathrm{PO}_{4}^{3-}\end{array}$ & 17 \\
\hline 604 & 602 & 605 & 605 & 605 & 605 & 605 & $\begin{array}{l}\mathrm{U}_{4} \text { asymmetric bending mode of } \\
\mathrm{O}-\mathrm{P}-\mathrm{O} \text { in } \mathrm{PO}_{4}{ }^{3-}\end{array}$ & 8 \\
\hline 563 & 559 & 563 & 563 & 565 & 567 & 567 & $\begin{array}{l}\mathrm{U}_{4} \text { asymmetric bending mode of } \\
\text { O-P-O in } \mathrm{PO}_{4}{ }^{3-}\end{array}$ & 15 \\
\hline 472 & 470 & 471 & 467 & 461 & 471 & 471 & $\begin{array}{l}\mathrm{U}_{2} \text { Symmetric bending mode of } \\
\mathrm{O}-\mathrm{P}-\mathrm{O} \text { in } \mathrm{PO}_{4}{ }^{3-}\end{array}$ & 1 \\
\hline
\end{tabular}

\subsection{Micro Raman Analysis}

Figures S5 and S6 represent the Raman spectra of pure, $\mathrm{ZnHA}_{\mathrm{p}}$ and $\mathrm{MgHA}$ s samples respectively. Figure 3 shows the Raman spectra of pure, $5 \% \mathrm{ZnHA}_{\mathrm{P}}$ and 5\% MgHA . Table 5 depicts the Raman vibrational assignment of pure, $\mathrm{Zn}$ and $\mathrm{Mg}$ doped $\mathrm{HA}_{\mathrm{P}}$. Phosphate posses four vibrational modes $\mathrm{U}_{1}, \mathrm{U}_{2}, \mathrm{U}_{3}$, and $\mathrm{U}_{4}$. The vibrational modes of $\mathrm{PO}_{4}{ }^{3-}$ present in all the Raman spectra confirm the hydroxyapatite structure in the 
samples. Table 5 depicts the Raman vibrational assignment of pure, $\mathrm{Zn}$ and $\mathrm{Mg}$ doped $\mathrm{HA}$. The FWHM of $\mathrm{U}_{1}$ peak $\left(962 \mathrm{~cm}^{-1}\right)$ increases with the dopant concentration. The $U_{2}$ peak position in doped $H A_{p}$ samples shift from $459 \mathrm{~cm}^{-1}$ to $485 \mathrm{~cm}^{-1}$ and it becomes strong. The $v_{3}\left(1035 \mathrm{~cm}^{-1}\right)$ and $\mathrm{v}_{4}\left(583 \mathrm{~cm}^{-1}\right)$ peaks shift to higher wavenumber. The shift of $\mathrm{v}_{2}, \mathrm{v}_{3}$, and $\mathrm{v}_{4}$ peak from lower to higher wavenumber is due to the following reasons; (i) the ionic radius of $\mathrm{Ca}^{2+}$ is more than dopant ions (ii) metal-oxygen distance of $\mathrm{Zn}$ and $\mathrm{Mg}$, is smaller than $\mathrm{Ca}-\mathrm{O}$ distance (iii) dopant ions decrease the cell volume of $\mathrm{HA}_{\mathrm{p}}$. The metal-oxygen distance of $\mathrm{Ca}$, $\mathrm{Zn}$, and $\mathrm{Mg}$ are $2.668,1.875$, and $1.743 \AA$ r respectively. The continuous increase in FWHM reveals an increase in crystal disorder provoked by the $\mathrm{Zn}$ and $\mathrm{Mg}$ dopants in $\mathrm{HA}_{\mathrm{p}}$, so the intensity of the vibrations decreases.

Furthermore, the peak at $1119 \mathrm{~cm}^{-1}$ and $1464 \mathrm{~cm}^{-1}$ indicate $\mathrm{CO}_{3}{ }^{2-}$ present in $\mathrm{HA}_{\mathrm{p}}$. The $\mathrm{v}_{1}\left(1119 \mathrm{~cm}^{-1}\right)$ and $\mathrm{v}_{3}$ $\left(1119 \mathrm{~cm}^{-1}\right)$ peaks are symmetric and asymmetric stretching vibrational modes of $\mathrm{CO}_{3}$ respectively [22]. The insert figure $\mathrm{f}$ in Fig. 3 shows the $\mathrm{U}_{3}$ asymmetric stretching vibration of $\mathrm{CO}_{3}$. The peaks appearing at $519(\mathrm{vw})$ and $440(\mathrm{w}) \mathrm{cm}^{-1}$ are the representatives of dopants $\mathrm{Mg}$ and $\mathrm{Zn}$ respectively [23, 24]. The peaks of $\mathrm{Zn}$ and $\mathrm{Mg}$ are illustrated as insert figures $d$ and e in Fig. 3 respectively. These results are confirmed by Popa and his groups [4]. Raman spectra results support the FT-IR results. 
Table 5

Raman vibrational mode assignment of pure, $\mathrm{Zn}$ and $\mathrm{Mg}$ doped $\mathrm{HA}$.

\begin{tabular}{|c|c|c|c|c|c|c|c|c|}
\hline \multirow[t]{2}{*}{$\begin{array}{l}\text { Pure } \\
\text { HAp }\end{array}$} & \multicolumn{3}{|c|}{ Zinc doped HAp } & \multicolumn{3}{|c|}{$\begin{array}{l}\text { Magnesium doped } \\
H A_{p}\end{array}$} & \multirow[t]{2}{*}{ Assignment } & \multirow[t]{2}{*}{ References } \\
\hline & $1 \%$ & $3 \%$ & $5 \%$ & $1 \%$ & $3 \%$ & $5 \%$ & & \\
\hline 429 & 430 & 432 & 443 & 431 & 435 & 440 & $\begin{array}{l}\mathrm{U}_{2} \text { doubly degenerate bending } \\
\text { mode of } \mathrm{PO}_{4}{ }^{3-} \\
\text { (O-P-O bond) }\end{array}$ & 4,21 \\
\hline 459 & 486 & 485 & 485 & 480 & 484 & 485 & $\begin{array}{l}\mathrm{U}_{4} \text { triply degenerate bending } \\
\left.\text { mode of } \mathrm{PO}_{4}{ }^{3-} \text { ( O-P-O bond }\right)\end{array}$ & 4 \\
\hline 583 & 584 & 585 & 589 & 589 & 588 & 594 & $\begin{array}{l}\mathrm{U}_{4} \text { triply degenerate bending } \\
\text { mode of } \mathrm{PO}_{4}{ }^{3-} \text { ( O-P-O bond) }\end{array}$ & 4,21 \\
\hline 962 & 964 & 962 & 965 & 962 & 966 & 966 & $\begin{array}{l}\mathrm{U}_{1} \text { nondegenerate symmetric } \\
\text { stretching mode of } \mathrm{PO}_{4}^{3-} \\
(\mathrm{P}-\mathrm{O} \text { bond) }\end{array}$ & 4,21 \\
\hline 1035 & 1040 & 1036 & 1036 & 1032 & 1035 & 1053 & $\begin{array}{l}\mathrm{U}_{3} \text { triply degenerate asymmetric } \\
\text { stretching mode of } \mathrm{PO}_{4}{ }^{3-}(\mathrm{P}-\mathrm{O} \\
\text { bond) and } \mathrm{U}_{1} \text { symmetric } \\
\text { stretching mode of } \mathrm{CO}_{3}{ }^{2-}\end{array}$ & $4,21,22$ \\
\hline 1119 & 1123 & 1119 & 1123 & 1123 & 1129 & 1113 & $\begin{array}{l}\mathrm{U}_{1} \text { symmetric stretching mode of } \\
\mathrm{CO}_{3}{ }^{2-}\end{array}$ & 22 \\
\hline 1466 & 1466 & 1470 & 1468 & 1470 & 1467 & 1466 & $\begin{array}{l}\mathrm{U}_{3} \text { asymmetric stretching mode } \\
\text { of } \mathrm{CO}_{3}{ }^{2-}\end{array}$ & 22 \\
\hline
\end{tabular}

\subsection{X-ray Photoelectron Spectroscopy (XPS)}

XPS analysis is used to determine the oxidation state and the structural information of $\mathrm{ZnHA}_{\mathrm{p}}$ and $\mathrm{MgHA}$. The survey scan spectra of XPS in Fig. 4 indicates the presence of $\mathrm{Ca}, \mathrm{P}, \mathrm{O}$, and $\mathrm{C}$ in all the samples and their corresponding binding energy is $347.76,133.76,531.37$ and $285.26 \mathrm{eV}[25,26]$. Fig. S7 shows the Ca, P, O, and $\mathrm{C}$ individual XPS spectra. In this spectra P, C and O have a sharp single peak, but due to spin-orbit splitting Ca has $\mathrm{Ca} 2 \mathrm{p}_{3 / 2}$ and $\mathrm{Ca} 2 \mathrm{p}_{1 / 2}$ two sharp peaks. The peak at $531 \mathrm{eV}$ stands for $\mathrm{O}$ present in phosphate and the peak at $285 \mathrm{eV}$ is for carbon (NIST database). The C1s $(285.31 \mathrm{eV})$ peak is for adsorbed carbon. In the synthesis process, a very small amount of dopant was used, so the peaks corresponding to $\mathrm{Zn}$ and Mg are very weak. The XPS peak for the dopants $\mathrm{Zn}$ and Mg are shown as inset figures $b$ and $\mathrm{c}$ in Fig. 4. Table 6 represents the BE (binding energy) of the elements in the samples. Phosphorus possesses 2p3/2 and 2p1/2 states due to spin-orbit splitting in $\mathrm{ZnHA}_{\mathrm{p}}$. The binding energy of Zn2p1/2, Zn2p3/2, 3p, and 3d in ZnHAp XPS spectra is $1045,1022,45.18$ and $10.35 \mathrm{eV}$ respectively. Among the two $\mathrm{Zn}$ peaks, the 2p3/2 peak is tapered and is more 
intensive than $2 p 1 / 2$ and the area of the $Z n 2 p 3 / 2$ peak is more than that of $Z n 2 p 1 / 2$ due to spin-orbit $(j-j)$ coupling. Zn2p3/2 shows degeneracy in four states, whereas $Z n 2 p 1 / 2$ shows only in two states. The $Z n 2 p 3 / 2$ peak is associated with a satellite peak. The satellite peak of $Z n 2 p 1 / 2$ is located at higher binding energy approximately $23 \mathrm{eV}$ than the main $\mathrm{Zn2p} 3 / 2$ peak. The binding energy of $\mathrm{Zn} 2 \mathrm{p} 3 / 2$ is $1022 \mathrm{eV}$. It is nearly three times greater than the binding energy of $\mathrm{Ca}^{2+}$. Hence, more energy is required to substitute $\mathrm{Ca}^{2+}$ by $\mathrm{Zn}^{2+}$ during the synthesis of $\mathrm{ZnHA}_{p}$, the required energy may be obtained either through pressure or temperature, or both. The binding energy of Mg2s and Mg2p are 88.02 and $49.4 \mathrm{eV}$ respectively. There is no satellite peak for $\mathrm{Mg}$. $\mathrm{Zn}$ and $\mathrm{Mg}$ binding energy results are very close to the result obtained by Negrila et al. and Predoi et al. [27, 28]. There is no remarkable change observed in the binding energy of $\mathrm{Ca}, \mathrm{P}$, and $\mathrm{O}$ due to the dopants. The incorporation of dopant with $\mathrm{HA}_{\mathrm{p}}$ decreases the intensity of the $\mathrm{Ca} 2 \mathrm{p} 3 / 2$ peak. It implies that dopant ions decrease the $\mathrm{Ca}^{2+}$ ions present on the surface. The addition of dopant ions decreases crystallinity. These results support the XRD result. No other foreign element is found in the XPS spectra. The XPS result confirmed that the dopant elements occupied the $\mathrm{Ca}^{2+}$ position in the HAP structure. The XPS analysis successfully detected the presence of $\mathrm{Zn}$ and $\mathrm{Mg}$ in doped $\mathrm{HA}$, but XRD and FT-IR did not detect these elements. XPS results support the micro Raman analysis.

Table 6

The binding energy of the $\mathrm{Ca}, \mathrm{P}, \mathrm{O}, \mathrm{C}, \mathrm{Zn}$, and $\mathrm{Mg}$.

\begin{tabular}{|llllllllll|}
\hline Element Name & $\mathbf{1 s}$ & $\mathbf{2 s}$ & $\mathbf{2 p}$ & $\mathbf{2 \mathbf { p } _ { 3 / 2 }}$ & $\mathbf{2 \mathbf { p } _ { 1 / 2 }}$ & $\mathbf{3 s}$ & $\mathbf{3 p}$ & $\mathbf{3 d}$ & References \\
\hline $\mathrm{Ca}$ & & & & 347.76 & 351.2 & 48.9 & 25.09 & 25,26 \\
$\mathrm{P}$ & & & 133.76 & & & & 25,26 \\
\hline $\mathrm{O}$ & 531.4 & & & & & & 25,26 \\
$\mathrm{C}$ & 285.3 & & & & & & 25,26 \\
$\mathrm{Zn}$ & & & 1022 & 1045.02 & & 45.18 & 10.35 & 27 \\
$\mathrm{Mg}$ & & & & & & & & 28 \\
\hline
\end{tabular}

\subsection{FE-SEM Analysis}

Figures $\mathrm{S} 8$ and $\mathrm{S} 9$ show the FE-SEM images of pure and $\mathrm{Zn}$ doped $\mathrm{HA} \mathrm{A}_{\mathrm{p}}$ and $\mathrm{Mg}$ doped $\mathrm{HA} \mathrm{A}_{\mathrm{p}}$ samples respectively. Figure 5 shows the FE-SEM images of pure, $5 \% \mathrm{Zn}$ and $5 \% \mathrm{Mg}$ doped $\mathrm{HA}$. Pure and doped $\mathrm{HA}$ showed cylindrical and hexagonal morphology. In $\mathrm{Zn}^{2+}$ doped $\mathrm{HA}_{\mathrm{p}}$, one-dimensional growth has been promoted. The one-dimensional growth leads to the higher thermodynamic stability of the HAp. Because of decreasing crystallite size, grain size decreases. Micropores and porosity increase with the increase in $\mathrm{Mg}$ concentration in $\mathrm{HA}_{p}$. But the addition of zinc in $\mathrm{HA}_{p}$ decreases porosity. The osteoconductivity attains an adequate level when the micropores allow the flow of extracellular fluid through the inner structure of the biomedical device. The change in grain size and a slight variation in morphology are due to the dopant ion replacing $\mathrm{Ca}^{2+}$ in $\mathrm{HA}_{\mathrm{p}}$. The grain size of pure $\mathrm{HA}_{p}, 5 \% \mathrm{Zn}$ doped $\mathrm{HA}_{p}$, and $5 \% \mathrm{Mg}$ doped $\mathrm{HA}$ are 275, 510 and $251 \mathrm{~nm}$ respectively. The $5 \% \mathrm{Zn}$ added $\mathrm{HA} \mathrm{A}_{p}$ shows highly defined rod shape morphology. Figure $6(\mathrm{a}, \mathrm{b}, \mathrm{c}$, 
shows the EDX spectra of pure $\mathrm{HA}_{P}, \mathrm{ZnHA}_{P}$ and $\mathrm{MgHA}_{P}$ samples respectively. The sharp $\mathrm{Ca}, \mathrm{P}$, and $\mathrm{O}$ peaks in all the spectra indicate the presence of $\mathrm{HA}_{\mathrm{p}}$. EDX results confirm the presence of $\mathrm{Zn}, \mathrm{Mg}$ in doped HA $\mathrm{A}_{\mathrm{P}}$. The FESEM results are in good accord with Kanasan et al. and lqbal et al. findings [29, 30].

\subsection{TEM Analysis}

Figure 7 shows the TEM images of pure, $5 \% \mathrm{Zn}$ and $5 \% \mathrm{Mg}$ doped $\mathrm{HA}_{\mathrm{P}}$ separately. The TEM images show the non-uniform and hexagonal morphology of $\mathrm{HA}_{\mathrm{p}}$. In $\mathrm{Mg}$ doped samples, the spherical morphology is more dominant than the hexagonal morphology (indicated in $7 f$ ). So, the dopant changes the morphology of $H A_{P}$. The TEM image of $5 \% \mathrm{ZnHA}_{\mathrm{P}}$ shows rod shape morphology and this result matches with the FE-SEM result. The agglomeration of particles is to decreases energy due to interfacial bonding formed by dopants [15]. Therefore, particles are composed of smaller crystallites. Figure $7(\mathrm{~g}, \mathrm{~h}, \mathrm{i})$ represents the selected area electron diffraction (SAED) pattern of pure $\mathrm{HA}_{p}, 5 \% \mathrm{ZnHA}_{p}$, and $5 \% \mathrm{MgHA}_{p}$ respectively. The spots and the ring patterns conform to the polycrystalline nature of hydroxyapatite. The morphology observed in TEM is in resemblance with the FE-SEM morphology.

\subsection{Electrical Analysis \\ 3.7.1. Dielectric constant}

The variation of electrical capacitance and the dielectric constant, due to applied ac field is analysed. The dielectric constant $\left(\varepsilon^{\prime}\right)$ is determined using the following formula [31].

$\varepsilon^{\prime}={\frac{C t}{\varepsilon_{0} A}}_{1}$

Here $\mathrm{C}, \mathbb{Q}, \mathrm{A}$ and $\mathrm{t}$ represent the capacitance, permittivity of the vacuum, area and the average thickness of the disc respectively. Figs. S10 and S11 show the variation of dielectric constant with frequency and dopant concentration. The frequency dependents dielectric constant of the pure, $5 \% \mathrm{Zn}$, and $5 \% \mathrm{Mg}$ doped $\mathrm{HA}$ are given in Fig. 8. The estimated dielectric constant $\left(\varepsilon^{\prime}\right)$ values for different frequencies are given in Table 7. The dielectric constant decrease when the frequency increases, but it increases with the increase in the concentration of dopant. In the ac field, an induced electric dipole causes polarization. The change in dielectric constant is associated with four types of polarization they are electronic polarization, ionic polarization, orientation polarization and interfacial polarization. At low frequency, the storage of charges at the grain and in grain boundary causes large interfacial polarization so, the dielectric constant is high. At higher frequencies, dipoles cannot harmonize with the applied ac field so the decrease in interfacial and orientation polarization causes a reduction in the dielectric constant. At higher frequencies, the dielectric constant is only due to electronic and ionic polarization. In $\mathrm{HA}_{\mathrm{P}}$ electrical conduction is due to the movement of a proton between $\mathrm{O}^{2-}$ or an $\mathrm{OH}^{-}$interacting with the $\mathrm{PO}_{4}$ group along the c-axis. And also at elevated temperatures, $\mathrm{OH}^{-}$ion in $\mathrm{HA}_{\mathrm{P}}$ is responsible for electric conduction. At room temperature, electric conduction is due to the movement of proton in adsorbed or condensed water in $\mathrm{HA}_{P}$ [31]. The incorporation of $\mathrm{Zn} / \mathrm{Mg}$ into the $\mathrm{Ca}$ site in the $\mathrm{HA}_{P}$ structure changes the dipole moment of the $\mathrm{OH}^{-}$ions. The addition of dopant in $\mathrm{HA}_{\mathrm{p}}$ causes shrinkage in structure, crystallographic defects and mobility of charge carriers hence the dielectric constant increases. The XRD result clearly shows that, as the dopant concentration in $\mathrm{HA}_{P}$ increases, the crystallite size decreases but defects 
increase. When the dielectric constant is changed the spreading of electromagnetic fields in bone fractures is also changed. The increase in dielectric constant supports bone growth and promotes fracture healing. The $\mathrm{Zn}$ doped $\mathrm{HA}_{\mathrm{p}}$ possesses a more dielectric constant than the Mg doped $\mathrm{HA}_{\mathrm{p}}$.

Table 7

Dielectric constants of pure and metal ions doped $\mathrm{HA}_{\mathrm{p}}$ for different frequencies

\begin{tabular}{|lllll|}
\hline Sample/ Frequency & $\mathbf{3 0 k H z}$ & $\mathbf{4 0 k H z}$ & $\mathbf{5 0 k H z}$ & $\mathbf{6 0 k H z}$ \\
\hline Pure HA & 1.0 & 0.89 & 0.8 & 0.78 \\
\hline $1 \% \mathrm{ZnHA}_{P}$ & 11.66 & 10.46 & 9.62 & 8.92 \\
\hline $3 \% \mathrm{ZnHA}_{P}$ & 12.25 & 11.06 & 10.14 & 9.52 \\
\hline $5 \% \mathrm{ZnHA}_{P}$ & 13.23 & 11.95 & 11.03 & 10.26 \\
\hline $1 \% \mathrm{MgHA}_{P}$ & 8.31 & 7.54 & 7.19 & 6.46 \\
\hline $3 \% \mathrm{MgHA}_{P}$ & 9.42 & 8.48 & 7.86 & 7.30 \\
\hline $5 \% \mathrm{MgHA}_{P}$ & 10.76 & 9.71 & 8.97 & 8.36 \\
\hline
\end{tabular}

\subsubsection{Dielectric loss}

The dielectric material absorbs energy from the ac field, based on its capacity it holds one part of the energy and the remaining energy is lost in the form of heat at a particular frequency. This dissipated energy is considered as dielectric loss. The best dielectric material possesses the least amount of dielectric loss [32]. Figs. S12 and S13 represent the variations in dielectric loss with frequency for pure, Zn doped and Mg doped $\mathrm{HA}_{\mathrm{p}}$ samples respectively. Figure 9 represents the variation of dielectric loss with the frequency of the sample of pure and $5 \% \mathrm{ZnHA}_{p}$, and $5 \% \mathrm{MgHA}_{p}$. The factors affecting the dielectric loss are crystal structure, applied AC frequency, temperature, stricture defects, imperfections in the crystal lattice, micro cracks, dislocations and etc. Therefore the dielectric loss can be minimized by using proper material. The dielectric loss goes on decreasing with the increase of frequency and the increase in the concentration of dopant material. At low frequency, the movement of charge carriers dominating the polarization, to rotate the dipoles more energy is required hence dielectric loss increases. In all the cases, at lower frequencies, the dielectric loss increases drastically and then decreases gradually with an increase in frequency. The deviation in dielectric loss depends on the concentration of dopants and their nature. Among $\mathrm{Zn}$ and $\mathrm{Mg}$, at a particular frequency dielectric loss is more for $\mathrm{ZnHA}_{\mathrm{p}}$, less for $\mathrm{MgHA}_{\mathrm{p}}$. The high dielectric loss at low frequencies is due to the oscillations of the dipole. At a higher frequency, the ionic polarization ceases. Hence, the energy is not spent in rotating the dipole of the ions present in $\mathrm{HA}_{\mathrm{p}}$. Therefore, dielectric loss lowers.

\subsubsection{AC Conductivity}

Figures S14 and S15 show the variation of ac conductivity due to the applied frequency and dopant concentration of the prepared samples. The frequency dependent of ac conductivity of pure, $5 \% \mathrm{Zn}$, and $5 \% \mathrm{Mg}$ 
doped $\mathrm{HA}_{\mathrm{p}}$ are given in Fig. 10. Table 8 shows the ac conductivity of pure, $\mathrm{Zn}$ and $\mathrm{Mg}$ doped $\mathrm{HA}_{\mathrm{P}}$ at different frequencies. The ac conductivity of the materials is determined by the following relation [32].

$\sigma_{\mathrm{ac}}=2 \pi f \varepsilon^{\prime} \varepsilon \bigotimes \tan \delta(2)$

Where $\mathrm{f}$ is the applied frequency of ac signal, tan $\delta, \varepsilon^{\prime}$ and $\varepsilon \rrbracket$ are the dielectric loss, dielectric constant and permittivity of vacuum respectively. Alternating current conductivity increase with increasing frequency, due to proton jumping of $\mathrm{O}^{2-}$ or due to the interaction of $\mathrm{OH}^{-}$ion bonded with $\mathrm{PO}_{4}$ group [33]. The AC conductivity of the sample decreases with the increase in dopant material concentration. The increase in dopant concentration causes an increase in dielectric constant and a decrease in conductivity. The results of the dielectric constant give well supports for the conductivity result. The calculated ac conductivity values are in order of $10^{-6} \mathrm{Sm}^{-1}$.

Table 8

Ac conductivity of the samples at different frequencies is given in $10^{-6} \mathrm{~S} / \mathrm{m}$.

\begin{tabular}{|c|c|c|c|c|c|}
\hline \multirow[t]{2}{*}{ S. No. } & \multirow[t]{2}{*}{ Sample } & \multicolumn{4}{|c|}{ Frequency } \\
\hline & & $30 \mathrm{kHz}$ & $40 \mathrm{kHz}$ & $50 \mathrm{kHz}$ & $60 \mathrm{kHz}$ \\
\hline 1 & Pure $\mathrm{HA}_{\mathrm{P}}$ & 6.32 & 6.68 & 6.99 & 7.29 \\
\hline 2 & $1 \% \mathrm{ZnHA}_{\mathrm{P}}$ & 5.26 & 5.53 & 5.63 & 5.76 \\
\hline 3 & $3 \% \mathrm{ZnHA}_{\mathrm{P}}$ & 4.45 & 4.59 & 4.73 & 4.82 \\
\hline 4 & $5 \% \mathrm{ZnHA}_{\mathrm{P}}$ & 3.81 & 3.95 & 4.05 & 4.14 \\
\hline 5 & $1 \% \mathrm{MgHA}_{P}$ & 4.36 & 4.62 & 4.68 & 4.80 \\
\hline 6 & $3 \% \mathrm{MgHA}_{\mathrm{P}}$ & 3.76 & 3.93 & 4.04 & 4.12 \\
\hline 7 & $5 \% \mathrm{MgHA}_{\mathrm{P}}$ & 3.25 & 3.42 & 3.49 & 3.56 \\
\hline
\end{tabular}

\subsection{Micro-hardness}

The Vickers hardness tester is used to find the micro-hardness. All the prepared samples are made into discs separately, each of diameter $13 \mathrm{~mm}$ and average thickness of $2 \mathrm{~mm}$. The estimated micro-hardness values, for loads 25, 50 and 100 grams are given in Table 9. The Vickers hardness (HV) can be determined by using the following relation [34].

$H_{r}=1.8544 \frac{P}{d^{2}} 3$

Where $\mathrm{P}$ is the applied load in $\mathrm{kg}$ and $\mathrm{d}$ is the diagonal length in $\mu \mathrm{m}$. The hardness of all the samples is increasing with the increase in load as well as the increase in dopants concentration. The addition of dopants decreases the crystallite size and increases the surface area, the driving force for densification, leading to higher mechanical properties. As the dopants are smaller in size as compared to Ca, the replacement of Ca by 
dopants would reduce the bond length and increase the bond strength with 0 . The increase in bond strength is the cause of the increase in hardness. So the samples become more compact and harder in structure [35]. The hardness of $5 \% \mathrm{Zn}^{2+}$ doped $\mathrm{HA}_{\mathrm{p}}$ and $5 \% \mathrm{Mg}^{2+}$ doped $\mathrm{HA}$ are $1059 \mathrm{MPa}$ and $1081 \mathrm{MPa}$ respectively for a 100 gram load. At higher loads, the plastic flow of the material is less, hence the resistance offered by the material is more. Therefore, the magnitude of microhardness increases with an increase in load. The higher hardness enhances cell attachment and proliferation.

Table 9

Micro-hardness for a different load of pure, $\mathrm{Zn}$ and $\mathrm{Mg}$ doped $H A_{p}$.

\begin{tabular}{|llll|}
\hline Sample & \multicolumn{3}{l|}{ Micro-hardness (Hv) } \\
\cline { 2 - 4 } & Load $\mathbf{2 5} \mathbf{g}$. & Load $\mathbf{5 0} \mathbf{g}$. & Load $\mathbf{1 0 0} \mathbf{~ g . ~}$ \\
\hline Pure HA & 20.1 & 38.8 & 71.1 \\
\hline $1 \% \mathrm{ZnHA}_{P}$ & 56.6 & 67.6 & 85.3 \\
\hline $3 \% \mathrm{ZnHA}_{P}$ & 59.2 & 70.6 & 95 \\
\hline $5 \% \mathrm{ZnHA}_{P}$ & 67.1 & 78 & 108 \\
\hline $1 \% \mathrm{MgHA}_{P}$ & 59.6 & 64.8 & 79.4 \\
\hline $3 \% \mathrm{MgHA}_{P}$ & 64.2 & 68.6 & 85.7 \\
\hline $5 \% \mathrm{MgHA}_{P}$ & 71.7 & 86.9 & 110.3 \\
\hline
\end{tabular}

\subsection{Vibrating Sample Magnetometer (VSM)}

The magnetic behavior of the prepared samples is analyzed by using a vibrating sample magnetometer with the magnetic field of -3 to +3 T. Figs. S16, S17, S18 and S19 represent the as-prepared and annealed sample's magnetic behavior, in the external magnetic field. Figures 11 and 12 represents the pure, $5 \% \mathrm{Zn}$ and $5 \% \mathrm{Mg}$ doped $\mathrm{HA}_{p}$ as prepared and annealed samples respectively. The slope of the magnetic moment and field curve gives the susceptibility of the material. It is evident from the $\mathrm{M}-\mathrm{H}$ curve all the prepared samples possess negative susceptibility. The pure, doped $\mathrm{HA}_{p}$, of as-prepared, annealed samples are diamagnetic [36]. The susceptibility of the material changes with dopant concentration. Hence, the addition of $\mathrm{Zn}^{2+} / \mathrm{Mg}^{2+}$ with pure $\mathrm{HA}_{p}$ increases the mechanical properties without any change in the magnetic property.

\subsection{Antibacterial Activity}

The antibacterial activity of the samples is analyzed against the Gram-positive Staphylococcus aureus and Streptococcus pneumoniae and Gram-negative Escherichia coli and Shigelladysenteriae bacteria by using the disc diffusion method. Erythromycin is used as positive control and pure $\mathrm{HA}_{\mathrm{p}}$ is used as a negative control. The zone of inhibition for each bacteria is measured and recorded in Table 10. The antibacterial activity of the samples is increased due to an increase in the concentration of dopants. And also antibacterial activity 
depends on the nature of the dopants [37]. The 5\% $\mathrm{ZnHA}_{p}$ and 5\% MgHA samples show the highest zone of inhibition against $S$. aureus and $S$. dysenteriae respectively. Antibacterial activity is related to the dielectric constant and is based on charge density. The increase in dielectric constant with an increase in the concentration of dopant causes increases in charge density hence antibacterial activity increases. The positive ion interacts with negative bacteria by giving a bacterial zone. The cation of the doped element exhibits antibacterial activity and leads the biomaterial towards medical applications [38]. Figs. S20 and S21 represent the antibacterial activity zone of inhibition of $\mathrm{ZnHA}_{\mathrm{p}}$ and $\mathrm{MgHA}_{\mathrm{p}}$.

Table 10

Zone of inhibition of antibacterial activity.

\begin{tabular}{|c|c|c|c|c|c|c|c|c|c|}
\hline \multirow[t]{2}{*}{ Sample name } & \multirow{2}{*}{$\begin{array}{l}\text { Bacteria } \\
\text { name }\end{array}$} & \multicolumn{8}{|c|}{ Zone of inhibition (mm) } \\
\hline & & $1 \%$ & & $3 \%$ & & $5 \%$ & & $H A_{P}$ & Erythromycin \\
\hline \multirow[t]{4}{*}{$Z n H A_{P}$} & S. dysentery & & 13.5 & & 14.5 & & 15.5 & 12 & 12.5 \\
\hline & E.coli & & 16.5 & & 16.5 & & 17 & 15 & 17 \\
\hline & S.aureus & & 14 & & 16 & & 18.5 & 13 & 14 \\
\hline & S.pneumonia & & 16 & & 15.5 & & 18 & 15 & 14 \\
\hline \multirow[t]{4}{*}{$\mathrm{MgHA}_{\mathrm{P}}$} & S.dysentery & 16 & & 18 & & 20 & & 13.5 & 14 \\
\hline & E.coli & 16 & & 17 & & 18.5 & & 14.5 & 13 \\
\hline & S.aureus & 17 & & 18 & & 19 & & 14 & 15 \\
\hline & S.pneumonia & 16 & & 18 & & 18.5 & & 15 & 14 \\
\hline
\end{tabular}

\subsection{Antifungal activity}

The antifungal activity of the samples is investigated against the human pathogenic fungal strains Aspergillusniger and Candida albicans by well diffusion method. Here Fluconazole is used as positive control and pure $\mathrm{HA}_{\mathrm{p}}$ is used as a negative control. The obtained antifungal results are recorded in Table 11. Furthermore, the antifungal potential of nanoparticles depends on the size and shape of the particles. The antifungal activity of Aspergillusniger showed a better result than Candida albicans in both $\mathrm{ZnHA}_{\mathrm{p}}$ and $\mathrm{MgHA}_{\mathrm{p}}$. The zone of inhibition increases with the increase in the concentration of dopants. Among $\mathrm{Zn}$ and $\mathrm{Mg}$ dopants, $5 \% \mathrm{Mg}$ doped $\mathrm{HA}_{\mathrm{P}}$ shows the highest zone of inhibition against Aspergillusniger. The actual mechanism of the antifungal activity is, $\mathrm{ZnHA}_{p}$ and $\mathrm{MgHA}_{p}$ penetrate the fungal cell and hyphae, affecting the integrity of the plasma membrane. It leads to cell damage due to blocking nutrient uptake, promotion of chromosomal aberrations, mitochondrial oxidative stress and adenosine triphosphate (ATP) production is reduced. Besides, it is interrupted by fungal intracellular communication and it reduces the lifespan of fungi. Zn and $\mathrm{Mg}$-doped hydroxyapatite nanoparticles are found to damage cell membranes leading to leakage of cellular components and finally cell death [39]. Figs. S22 and S23 represent the antifungal activity zone of inhibition for $\mathrm{ZnHA}_{\mathrm{p}}$ and $\mathrm{MgHA}$. 


\section{Table 11}

\begin{tabular}{|c|c|c|c|c|c|c|}
\hline \multicolumn{7}{|c|}{ Zone of inhibition of the $\mathrm{Zn}^{2+}$ and $\mathrm{Mg}^{2+}$ doped $\mathrm{HA}_{\mathrm{p}}$. } \\
\hline \multirow[t]{2}{*}{ Sample name } & \multirow[t]{2}{*}{ Fungus name } & \multicolumn{5}{|c|}{ Zone of inhibition (mm) } \\
\hline & & $\mathrm{HA}_{\mathrm{P}}$ & $1 \%$ & $3 \%$ & $5 \%$ & Fluconazole(PC) \\
\hline \multirow[t]{2}{*}{$\mathrm{ZnHA}$} & Candida albicans & 12 & 13 & 16 & 18 & 11 \\
\hline & Aspergillusniger & 15 & 16 & 18 & 19 & 13 \\
\hline \multirow[t]{2}{*}{$\mathrm{MgHA}_{\mathrm{P}}$} & Candida albicans & 12 & 13 & 13 & 14 & 11 \\
\hline & Aspergillusniger & 15 & 17 & 19 & 21 & 13 \\
\hline
\end{tabular}

\subsection{Antibiofilm activity}

The Staphylococcus aureus (Gram-Positive) and Escherichiacoli (Gram-Negative) bacterial strains are used to analyse the antibiofilm activity of the prepared samples. Pure $\mathrm{HA}_{\mathrm{P}}$ is used as a control. The antibiofilm activity of $\mathrm{ZnHA}_{p}$ and $\mathrm{MgHA}_{p}$ are as shown in Figs. 13 and 14 respectively. The pure $\mathrm{HA}_{p}$ treated biofilm showed dense and strong adhesive biofilm formation on the glass substrates. The density of bacterial growth decreased with an increase in dopant concentration. Notably, ZnHA showed a better result than MgHA $\mathrm{A}_{p}$ [39]. The antibiofilm activity can be explained by stating that the $\mathrm{ZnHA}_{\mathrm{p}}$ samples enabled in migration of radical anions into the cell membrane and reacted with the thiol group of peptides/amino acid leading to loss of cell division, mesosoma function, intracellular cell signaling, intracellular electrolytes potential, protein and DNA synthesis.

\section{Conclusion}

In the present work, metal ions $\mathrm{Zn}^{2+}$ and $\mathrm{Mg}^{2+}$ are separately incorporated successfully with $\mathrm{HA}$. The physical, morphological, electrical, magnetic, antibacterial, antifungal, and antibioflim activities of the prepared samples are investigated. The XRD, micro Raman and XPS analysis findings revealed that dopant ions successfully replaced $\mathrm{Ca}$ from the $\mathrm{HA}_{\mathrm{p}}$ structure, but not in the $\mathrm{OH}$ position. The dopant decreases crystallite size and increases the surface area of $\mathrm{HA}_{p}$. Hence, the hardness of $\mathrm{HA}_{\mathrm{P}}$ increases. Subsequently, its strength and loadbearing capacity increase. The FE-SEM and TEM distinctly display the hexagonal morphology of the prepared samples. The increase in ionic polarization due to the addition of dopant in $\mathrm{HA}_{\mathrm{p}}$ increases the dielectric constant subsequently supports the bone growth in fracture heal applications. The increase in dielectric constant leads to an increase in charge density therefore the antibacterial activity also increases. The surface defects caused due to the addition of dopant also increases the biological activity. Among all the dopants, 5\% zinc doped $\mathrm{HA}_{P}$ shows the highest antibiofilm activity. The $5 \%$ magnesium doped $\mathrm{HA}$ shows the highest antibacterial and antifungal activity. The present work improved the strength, loadbearing capacity, dielectric constant and bioactivity of hydroxyapatite. Further, several analyses will be carried out in the future to improve the loadbearing capacity and the drug delivery with nanocomposites of hydroxyapatite.

\section{Declarations}




\section{Acknowledgement}

The research work done and presented in this paper is carried out with the financial support of the RUSA-Phase 2.0 grant sanctioned vide letter NO. F.24-51/2014-U, policy (TN Multi-Gen), Department of Education, Government of India, Dated 09.10.2018.

\section{References}

1. Veerla SC, Kim DR, J Kim J, et al. Controlled nanopaicle synthesis of Ag/Fe co-doped hydroxyapatite system for cancer cell treatment, Mater. Sci. Eng. C 2019, 98: 311-323.

2. Bhattacharjee P, Begam H, Chanda A, et al. Animal trial on zinc doped hydroxyapatite: A case study, J. Asian Ceram. Soc. 2014, 2: 44-51.

3. Iqbal N, Abdul Kadir MR, Mahmood NH, et al. Characterization, antibacterial and in vitro compatibility of zinc-silver doped hydroxyapatite nanoparticles prepared through microwave synthesis, Ceram. Int. 2014, 40: 4507-4513.

4. Popa CL, Deniaud A, Michaud-Soret I, et al. Structural and biological assessment of zinc doped hydroxyapatite nanoparticles, J. Nanomater. 2016, Article ID 1062878, doi.org/10.1155/2016/1062878

5. Walczyk D, Malena D, Krol M, et al. Physicochemical characterization of zinc-substituted calcium phosphates, Bull. Mater. Sci. 2016, 39: 525- 535.

6. Suchanek W, Yashima M, Kakiana M, et al. Hydroxyapatite ceramics with selected sintering additives, Biomaterials 1997, 18: 923-933.

7. Webster TJ, Massa-Schlueter E, Smith J, et al. Osteoblast response to hydroxyapatite doped with divalent and trivalent cations, Biomaterials 2004, 25: 2111-2121.

8. Venkatasubbu GD, Ramasamy S, Krishnan VR, et al. Nanocrystalline hydroxyapatite and zinc-doped hydroxyapatite as carrier material for controlled delivery of ciprofloxacin, Biotech. 1 (2011) 173-186.

9. Wang D, Yan T, Zhu W, et al. Preparation and properties of zinc-doped hydroxyapatite whisker, J. Applied Mechanics and Materials 2014, 487: 131-134.

10. Tite T, Popa AC, Balescu LM, et al. Cationic substitutions in hydroxyapatite: Current status of the derived biofunctional effects and ther In Vitro interrogation methods, Materials 2018, 11: 2081. doi:10.3390/ma11112081.

11. Kanasan N, Adzila S, Koh CT, et al.Effects of magnesium doping of the properties of hydroxyapatite/sodium alginate biocomposite, Adv. Appl. Ceram.118 (2019) 381-386.

12. Sallam SM, SaoedHanafi ME, Mohamed FA, et al. The dielectric study of calcium hydroxyl apatite doped by magnesium ions, Egypt. J. Biophys. Biomed.Eng. 2018, 19: DOI: 10.21608/ejbbe.2018.3208.1016.

13. Gamal GA, Arabia S, Said AH, Effect of iron additives on the microstructure of hydroxyapatite, ETASR 2013, 3(6): 532-539.

14. Sundarabharathi L, Ponnamma D, Parangsan $\mathrm{H}$, et al. Effect of anions on the structural, morphological and dielectric properties of hydrothermally synthesized hydroxyapatite nanoparticles, SN Applied Sciences 2020, 2(94): DOI; 10.1007/s42452-019-1807-3. 
15. Ofudie EA, Adeogun Al, Idowu MA, et al. Synthesis and characterization of Zn-doped hydroxuapatite: scaffold application, antibacterial and bioactivity studies, Heliyon 2019, 5:e01716.

16. Uysal I, Severcan F, Tezcaner A, et al. Co-doping of hydroxyapatite with zinc and fluoride improves mechanical and biological properties of hyroxyapatite, Prog. Nat. Sci.Mat. Int. 2014, 24: 340-349.

17. Popa CL, Deniaud A, Michaud-Soret I, et al. Structural and biological assessment of zinc doped hydroxyapatite nanoparticles, J Nanomater, 2016, 1: 1-10.

18. Hanafi MES, Sallam SM, Mohamed FA, Characterization of hydroxyapatite doped with different concentration of magnesium ions, IJRSSET. 2016, 3: 17-23.

19. Miculescu F, Mocanu AC, Stan GE, et al. Influence of the modulated two-step synthesis of biogenic hydroxyapatite on biomimetic products' surface, Appli. Surf.Sci.2018, 438: 147-157.

20. Puroniene IG, Stankeviciute Z, Ishikawa K, et al. Formation of calcium hydroxyapatite with high concentration of homogeneously distributed silver, Microporous Mesoporous Mater. 2019, DOl; 10.1016/j.micromeso.2019.109806.

21. Timchenko PE, Timchenko EV, Prisareva EV, et al. Spectral analysis of allogeneic hydroxyapatite powders, J. Phys. Conf. Ser. 2017, 784: 012060 doi:10.1088/1742 6596/784/1/012060.

22. Buzgar N, Apopel Al, The Raman study of certain carbonates,Analelestiintifice ale universitatii, " AL. I. CUZA" IASI Geologie. Tomul LV, nr 2009, https://www.researchgate.net/publication/210110408.

23. Emayavaramban PS, Babu G, Karvembu R, et al. Gold nanoparticles supported on magnesium oxidnanorods for oxidation of alcohols. JNN. 2016, 16: 2517-2526.

24. Gultekin D, Akbulut $\mathrm{H}$. Raman studies of ZnO products synthesized by solution based methods, Acta Phys. Plo. A 2016, 129: 803-805.

25. Lowry N, Han Y, Meenan BJ, et al. Strontium and zinc co-substituted nanophase hydroxyapatite, Ceram. Int. 2017, 43 (15): 12070-12078.

26. Lu HB, Cambell CT, Graham DJ, et al. Surface characterization of hydroxyapatite and related calcium phosphates by XPS and TOF-SIMS, Anal. Chem. 2000, 72: 2886-2894.

27. Negrila CC, Predoi MV, Iconaru SL, et al. Development of zinc doped hydroxyapatite by sol-gel method for medical applications, Molecules 2018, 23: 2986 doi:10.3390/molecules23112986.

28. Predoi D, Iconaru SL, Predoi MV, et al. Obtaining and characterizing thin layers of magnesium doped hydroxyapatite by dip coating procedure, Coatings 2020, 10: 510 doi:10.3390/coatings10060510.

29. Kanasan N, Adzila S, Koh CT, et al. Effects of magnesium doping on the properties of hydroxyapatite/sodium alginate biocomposite, ADV APPL CERAM 2019, 118(7): 381-386.

30. Iqbal N, Iqbal S, Iqbal T, et al. Zincdoped hydroxyapatite-Zeolite/Polycaprolactone composites coating on magnesium substrate for enhancing in -vitro corrosion and antibacterial performance, Trans. Nonferrous Met. Soc. China 2020, 30: 123-133.

31. Khouri AEl, Zegzouti A, Elaatmani M, et al. Bismuth-substituted hydroxyapatite ceramics synthesis: morphological, structural, vibrational and dielectric properties, 2019, doi.org/10.1016/j.inoche.2019.107568.

32. Nayak B, Misra PK, Exploration of the structural and dielectric characteristics of a potent hydroxyapatite coated gallium bioceramics for the forthcoming biomedical and orthopedic applications, Mater. Chem. 
Phys. 2020, 239: 121967. doi.org/10.1016/j.matchemphys.2020.123130.

33. Helen S, Ruban Kumar A, Study of structural, mechanical and dielectrical properties of ions doped apatite for antibacterial activity, Mater. Chem. Phys. 2019, 237:

121867, doi.org/10.1016/j.matchemphys.2019.121867.

34. Suthar SR, Jethva HO, Joshi MJ, Vickers micro-hardness studies of $\mathrm{Mn}^{++}$and $\mathrm{Cu}^{++}$doped calcium levotartrate tetrahydrate single crystals, IOSR-JAP 2018, 10: 5-12.

35. Sun ZP, Ercan B, Evis Z, et al. Microstructural, mechanical, and osteocompatibility properties of $\mathrm{Mg}^{2+} / \mathrm{F}^{-}$ doped nanophase hydroxyapatite, J Biomed Mater Res A. 2010, 93A (2): 411-418.

36. Chanda A, Gupta S, Vasundhara M, et al. Study of structural, optical and magnetic properties of cobalt doped ZnOnanorods. RSC Adv. 2017, 7: 50527-50536.

37. Gayathri B, Muthukumarasamy, Delauthapilli V, et al. Magnesium incorporated hydroxyapatite nanopartickes: Preparation, characterization, antibacterial and larvicidal activity, ARAB J CHEM 2018, 11: 645-654.

38. Helen S, Rubankumar A, Electrical, mechanical and surface analysis on ion-doped hydroxyapatite for antibacterial activity. Appl. Phys. A 2018, 124: 535 (1-5).

39. Groza A, Ciobanu CS, Popa CL, et al. Structural Properties and Antifungal Activity against Candida albicans Biofilm of Different Composite Layers Based on Ag/Zn Doped HydroxyapatitePolydimethylsiloxanes. Polymers 2016, 8(131): 1-22.

\section{Figures}




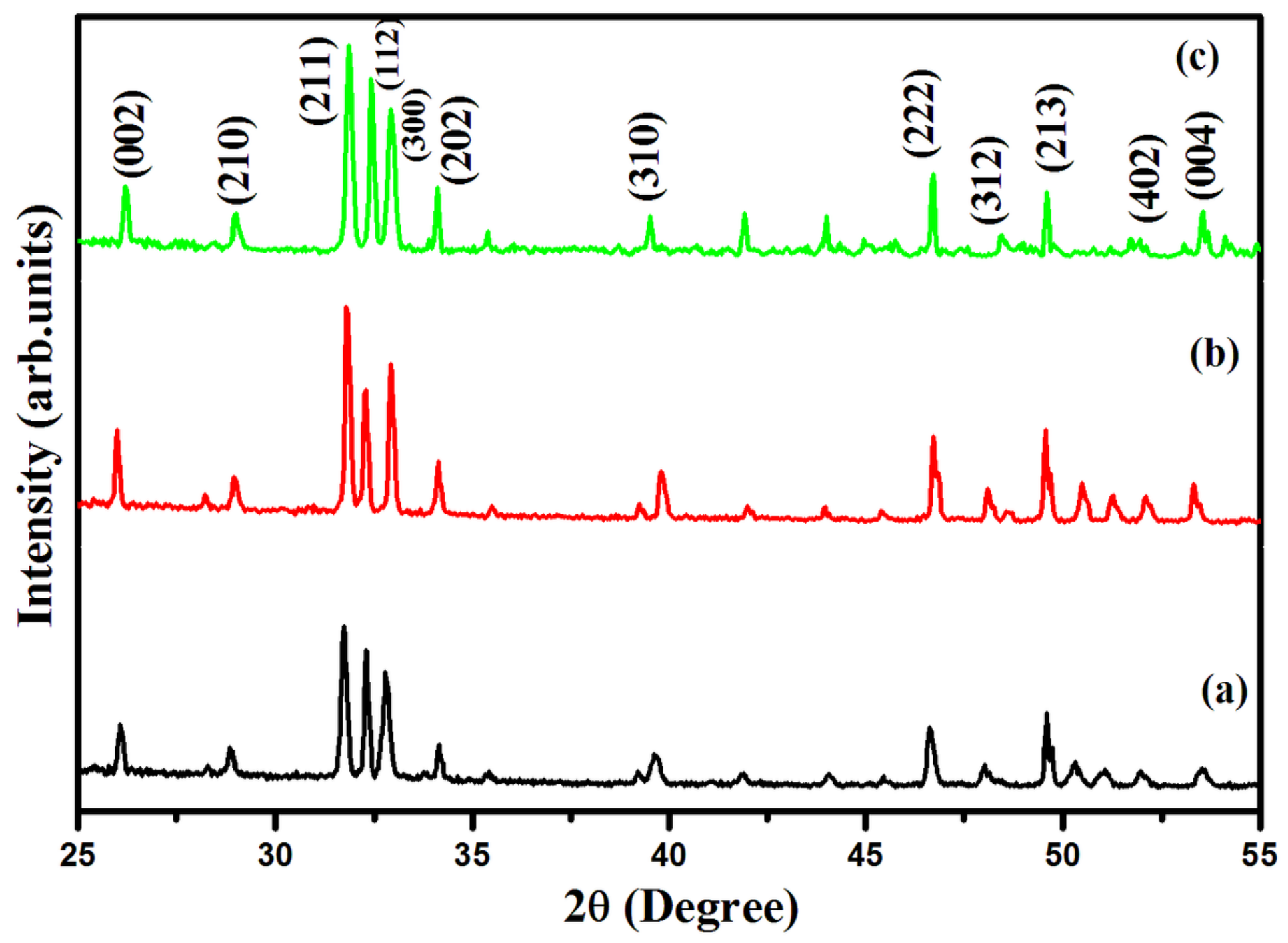

Figure 1

XRD patterns of (a) pure HAP, (b) 5\% ZnHAP and (c) 5\% MgHAP. 


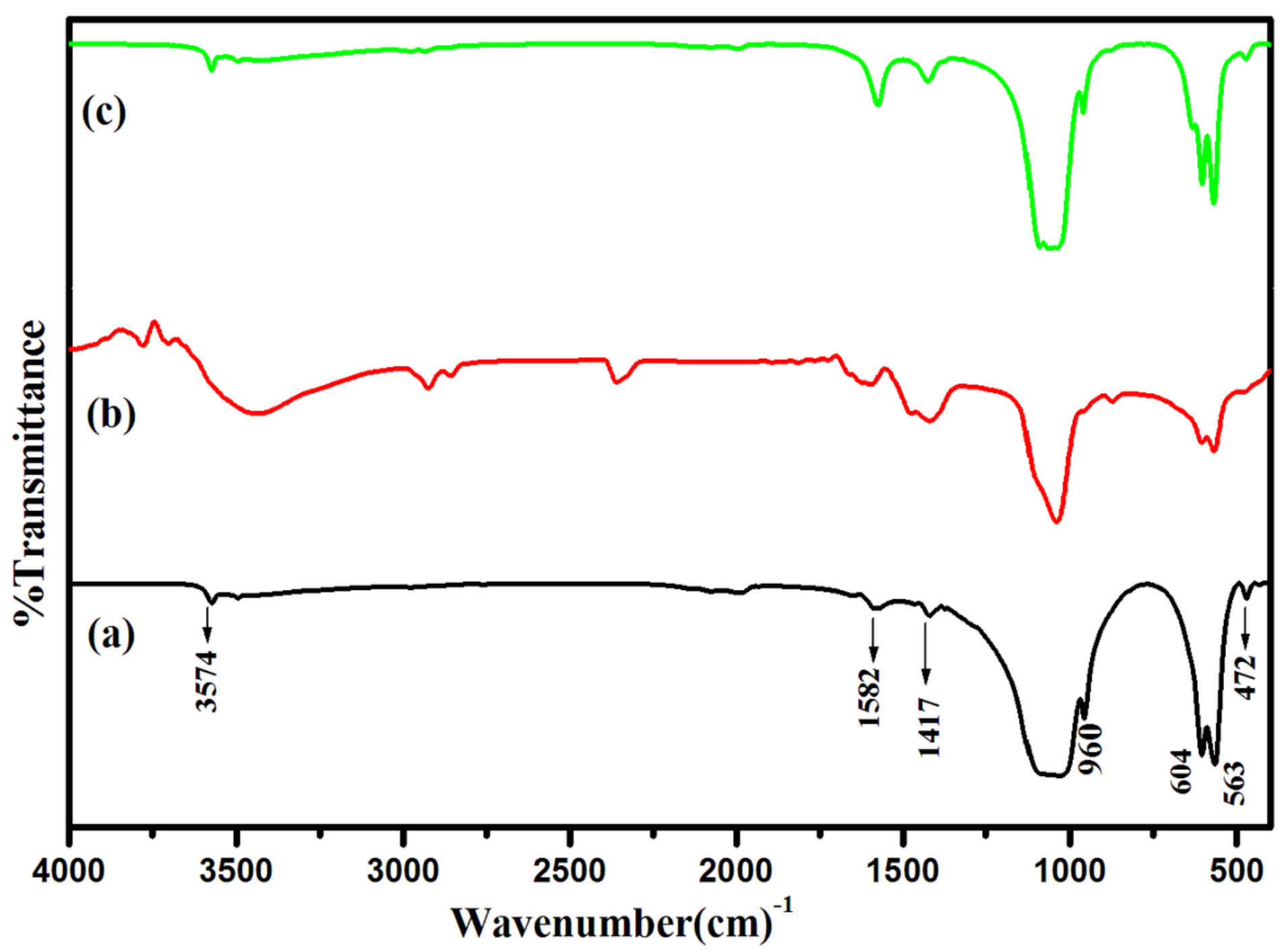

Figure 2

FT-IR spectra of (a) pure HAP, (b) 5\% ZnHAP and (c) 5\% MgHAP. 


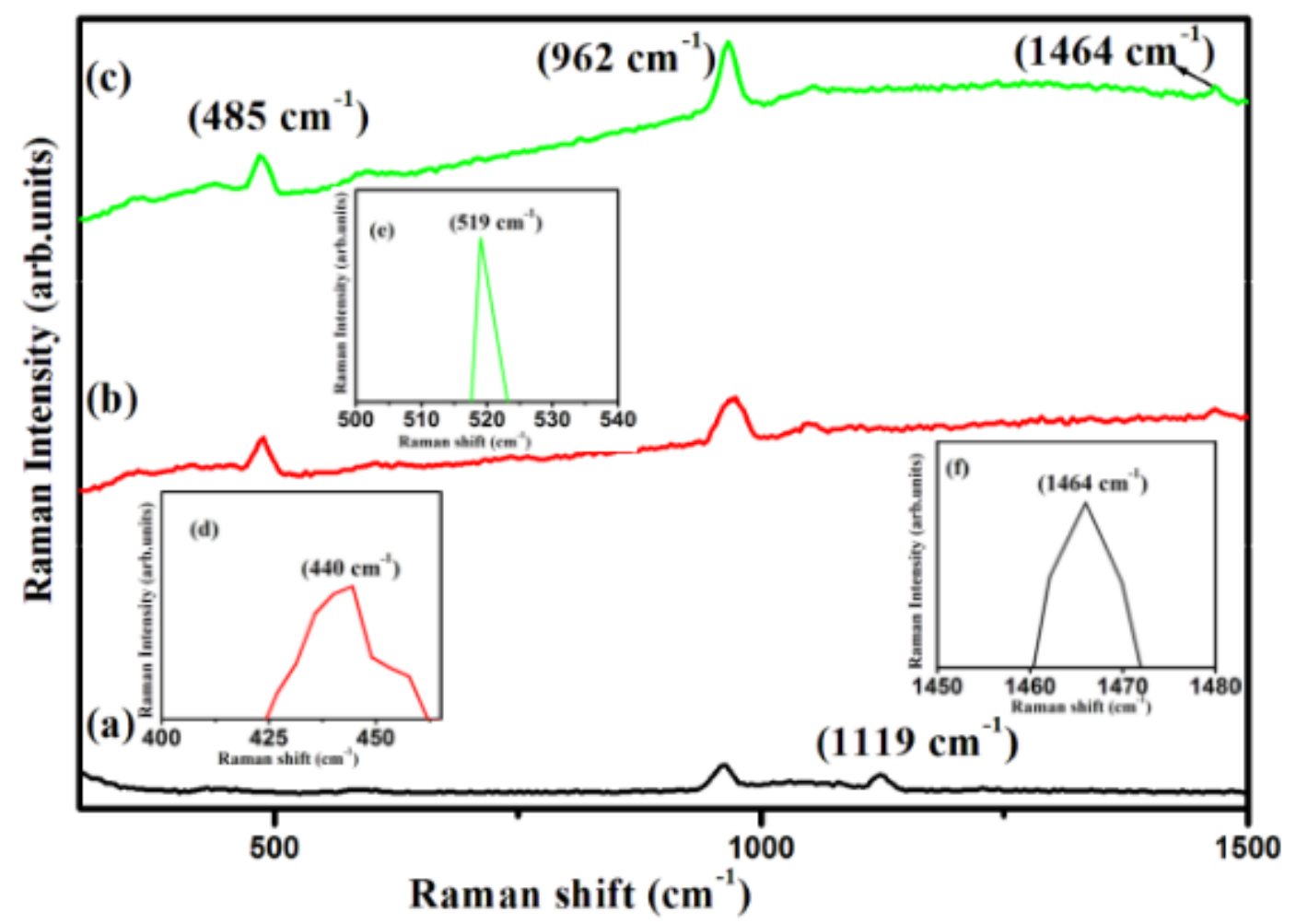

Figure 3

micro Raman spectra of (a) pure HAP, (b) 5\% ZnHAP and (c) 5\% MgHAP. 

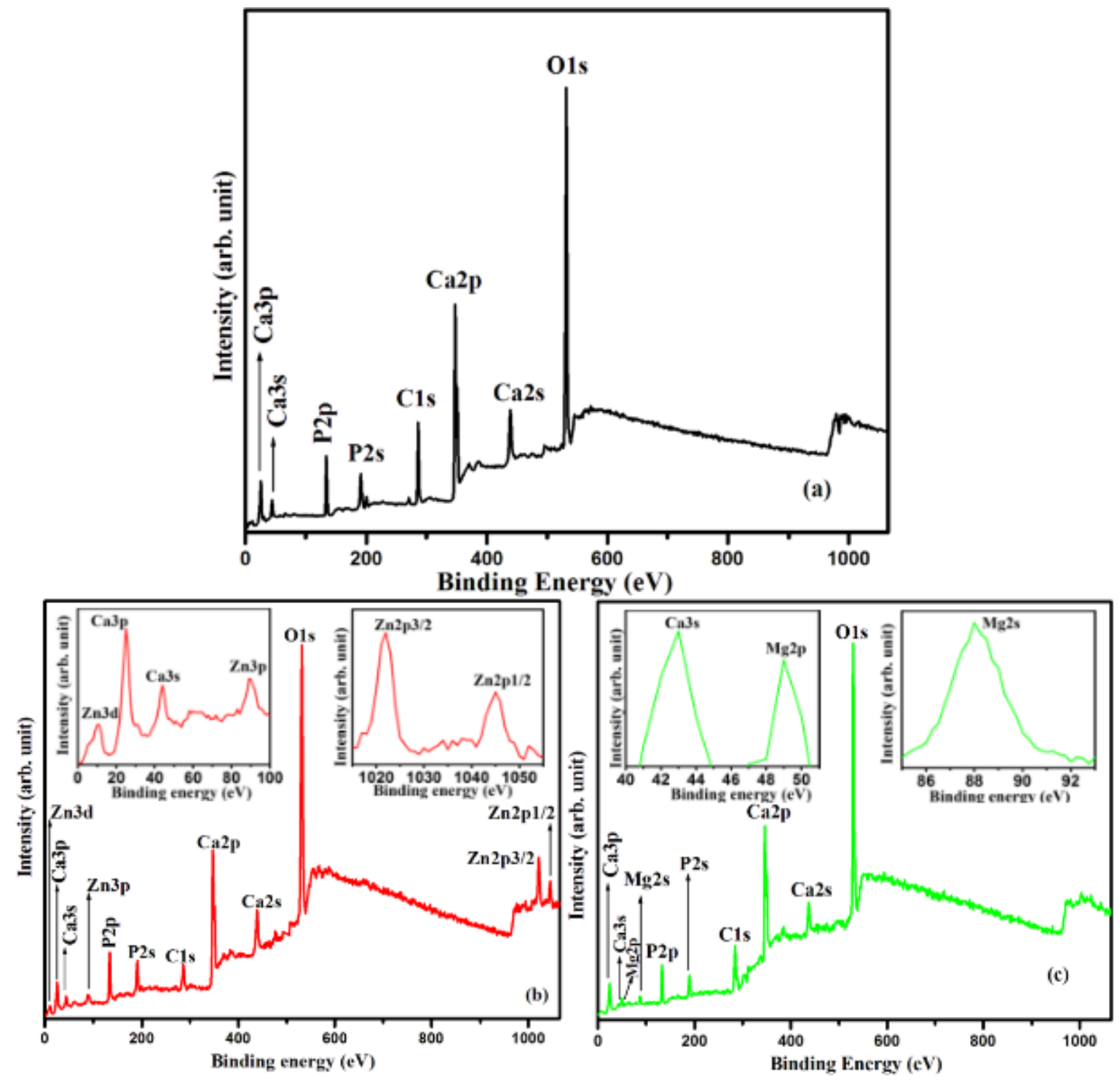

Figure 4

XPS surveys scan spectra of (a) pure HAP, (b) $5 \%$ ZnHAP and (c) $5 \%$ MgHAP 


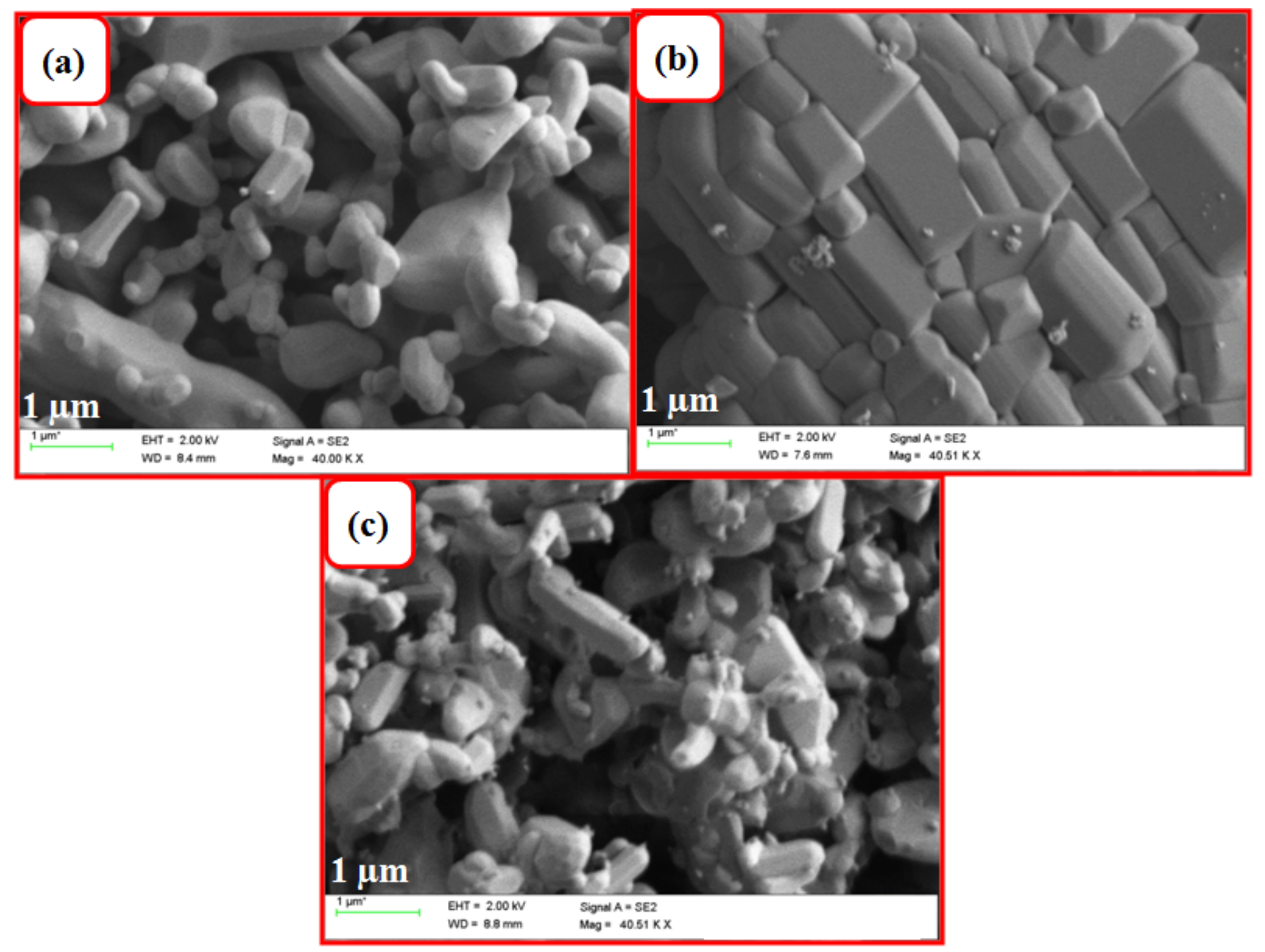

Figure 5

FE-SEM images of (a) pure HAP, (b) 5\% ZnHAP and (c) 5\% MgHAP. 

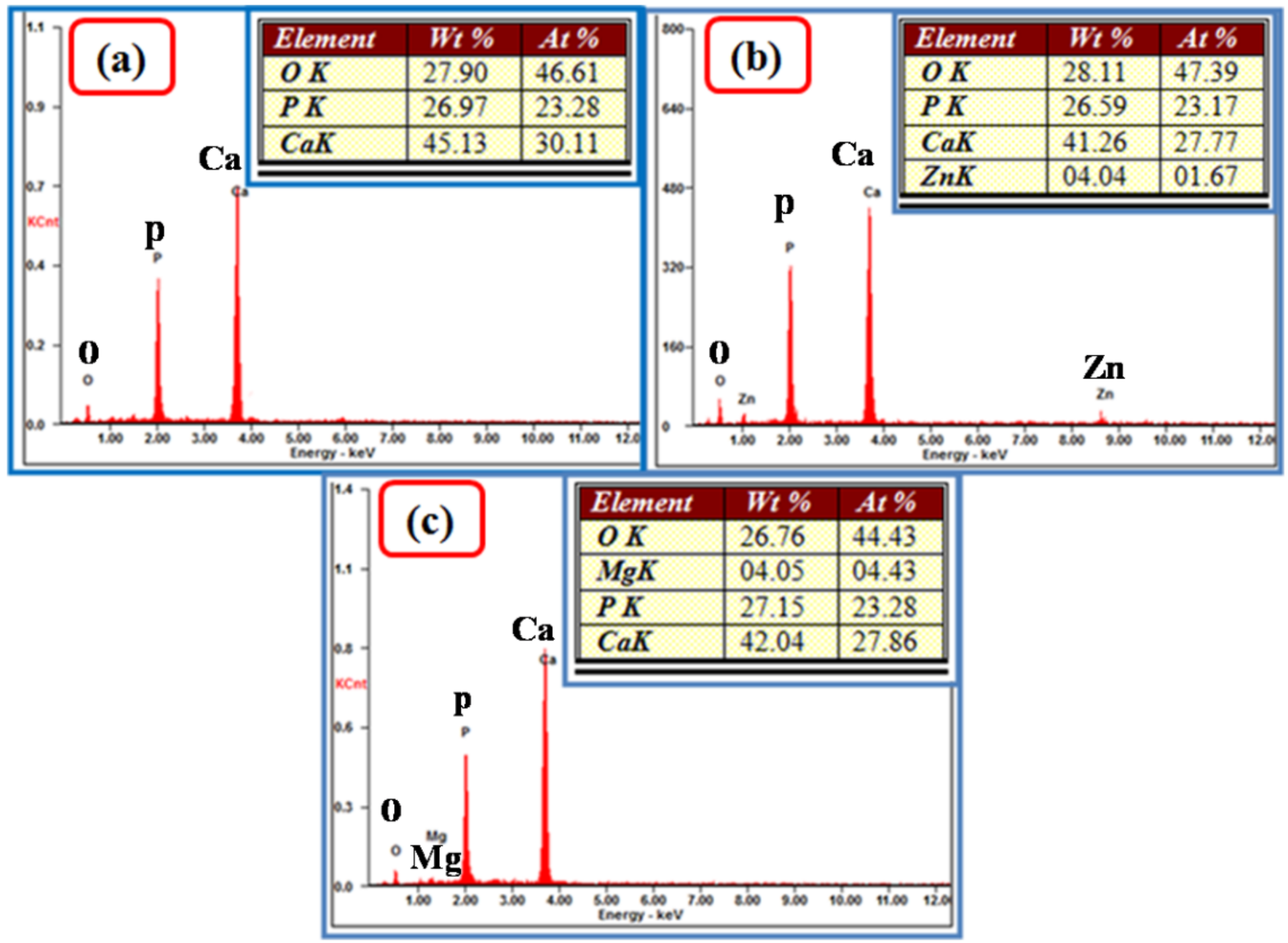

Figure 6

EDX spectra of (a) pure HAP, (b) 5\% ZnHAP and (c) 5\% MgHAP. 


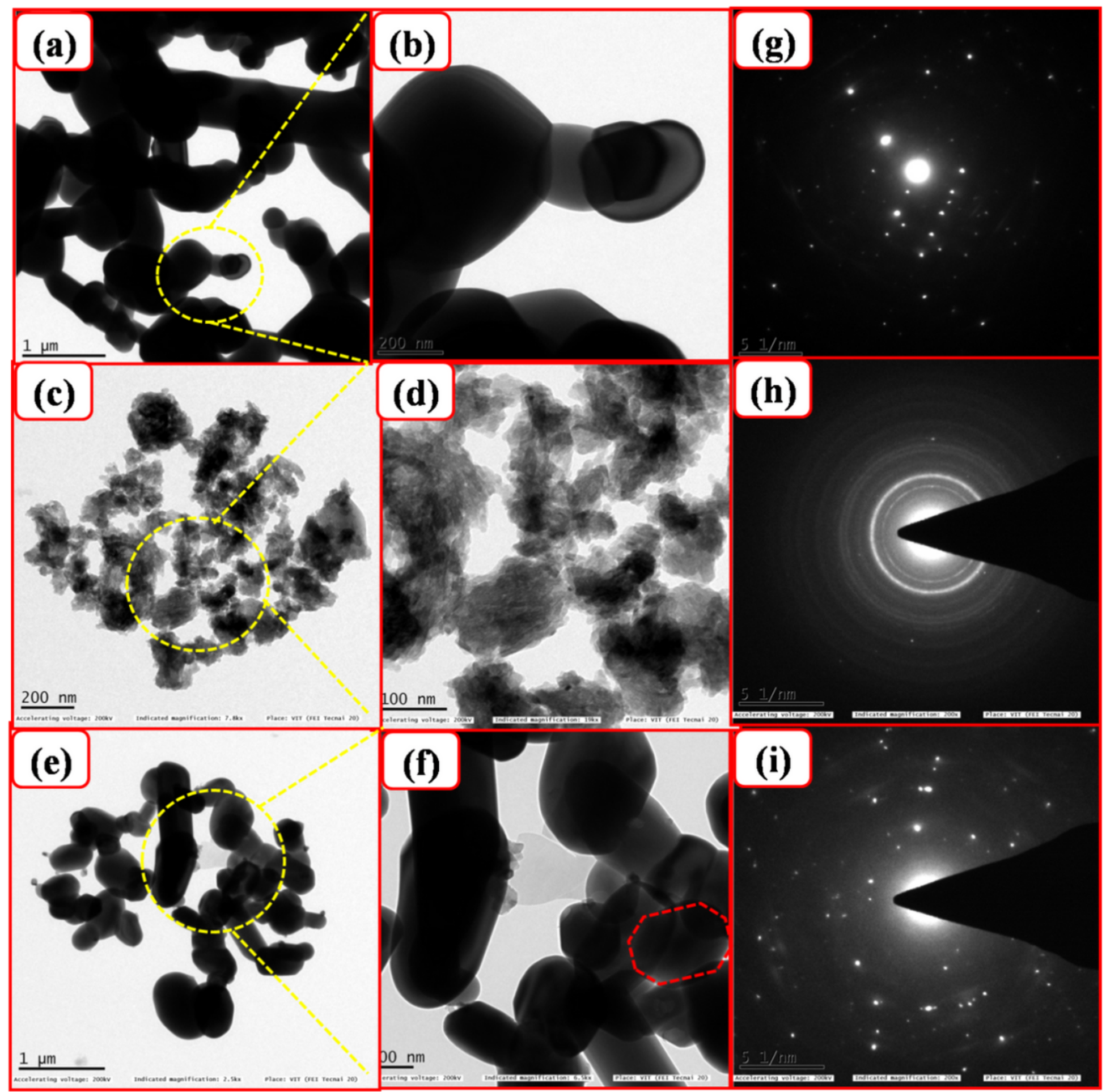

Figure 7

TEM images of $(a, b)$ pure, $(c, d) 5 \% \mathrm{Zn}$ and $(e, f) 5 \% \mathrm{Mg}$ doped HAP and the images $\mathrm{g}$, $\mathrm{h}$ and $\mathrm{i}$ are the SEAD patterns of pure HAP, Zn and Mg doped HAP respectably. 


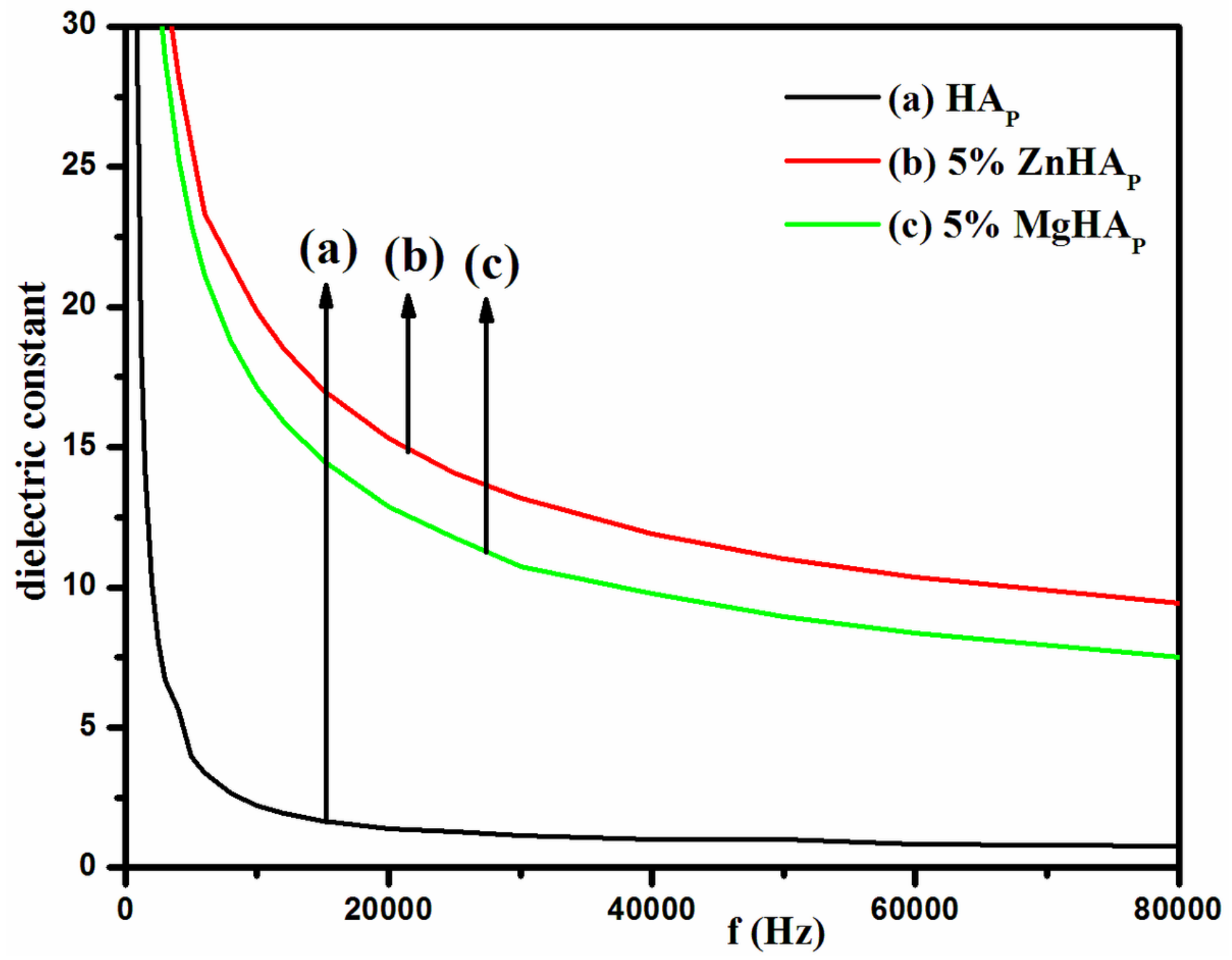

Figure 8

Dielectric Constant of pure HAP, $5 \%$ ZnHAP and $5 \%$ MgHAP with a function of frequency 


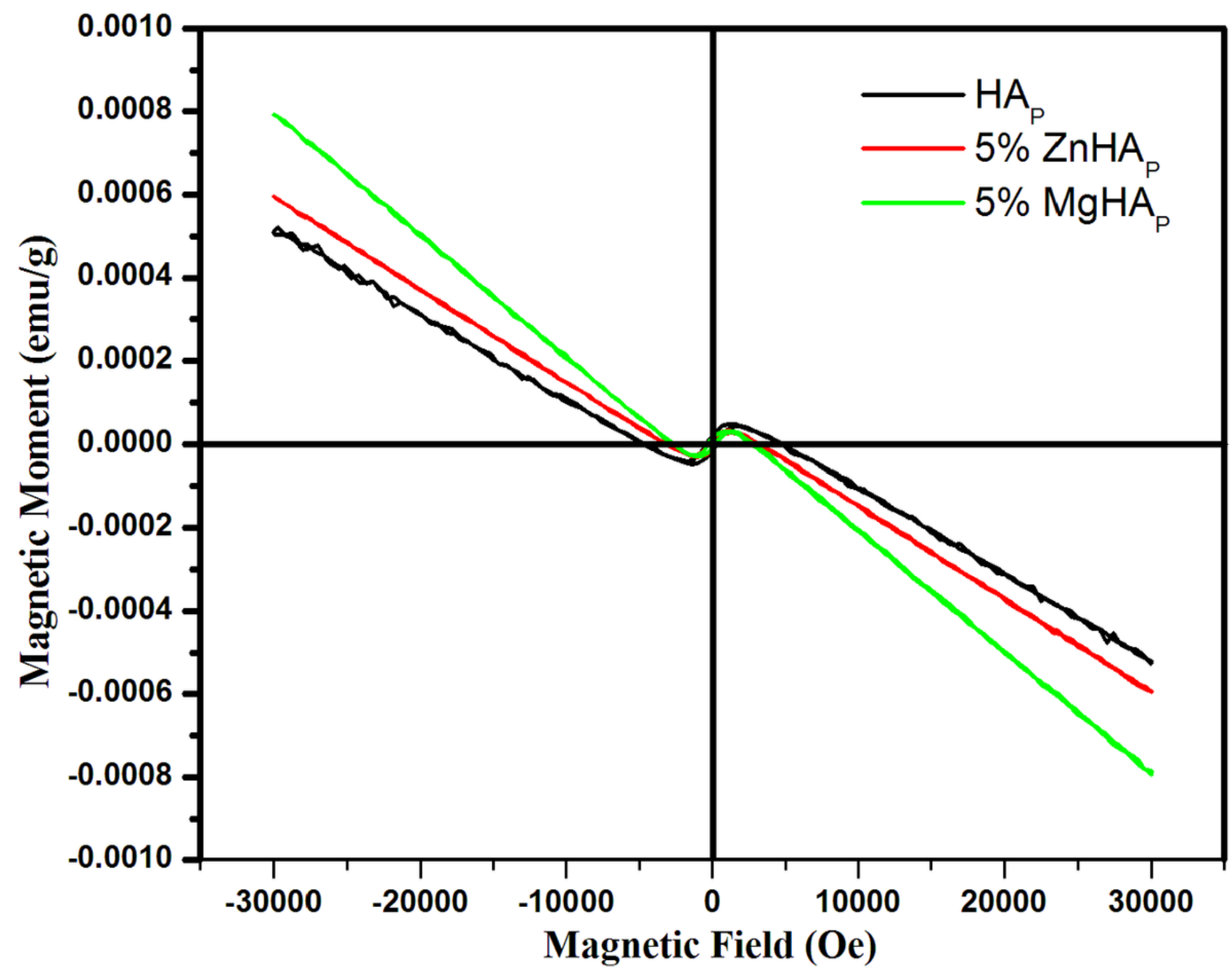

Figure 9

Dielectric loss of pure HAP, $5 \%$ ZnHAP and 5\% MgHAP with a function of frequency 


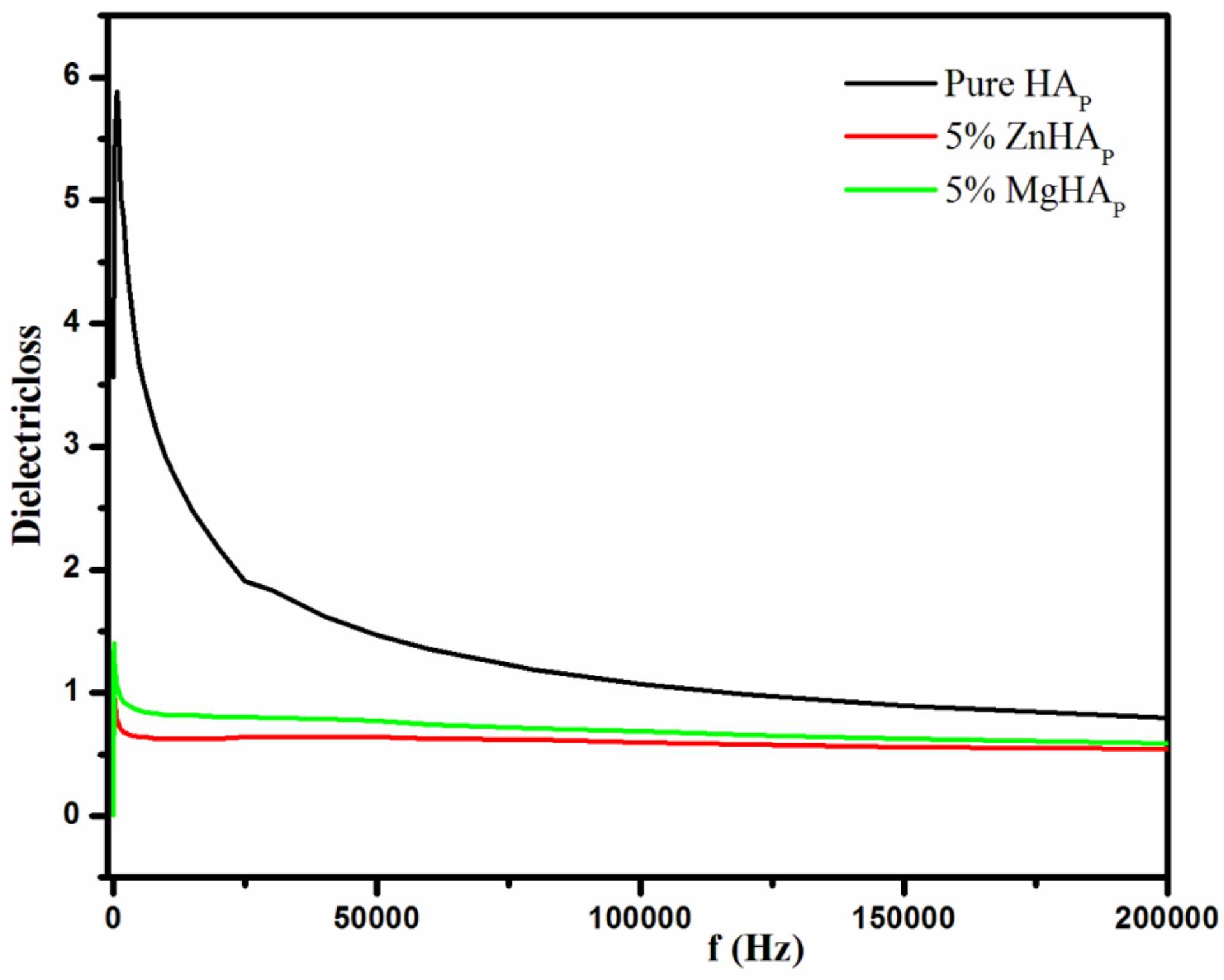

Figure 10

Conductivity as a function of the frequency of pure HAP and metal ions doped HAP. 


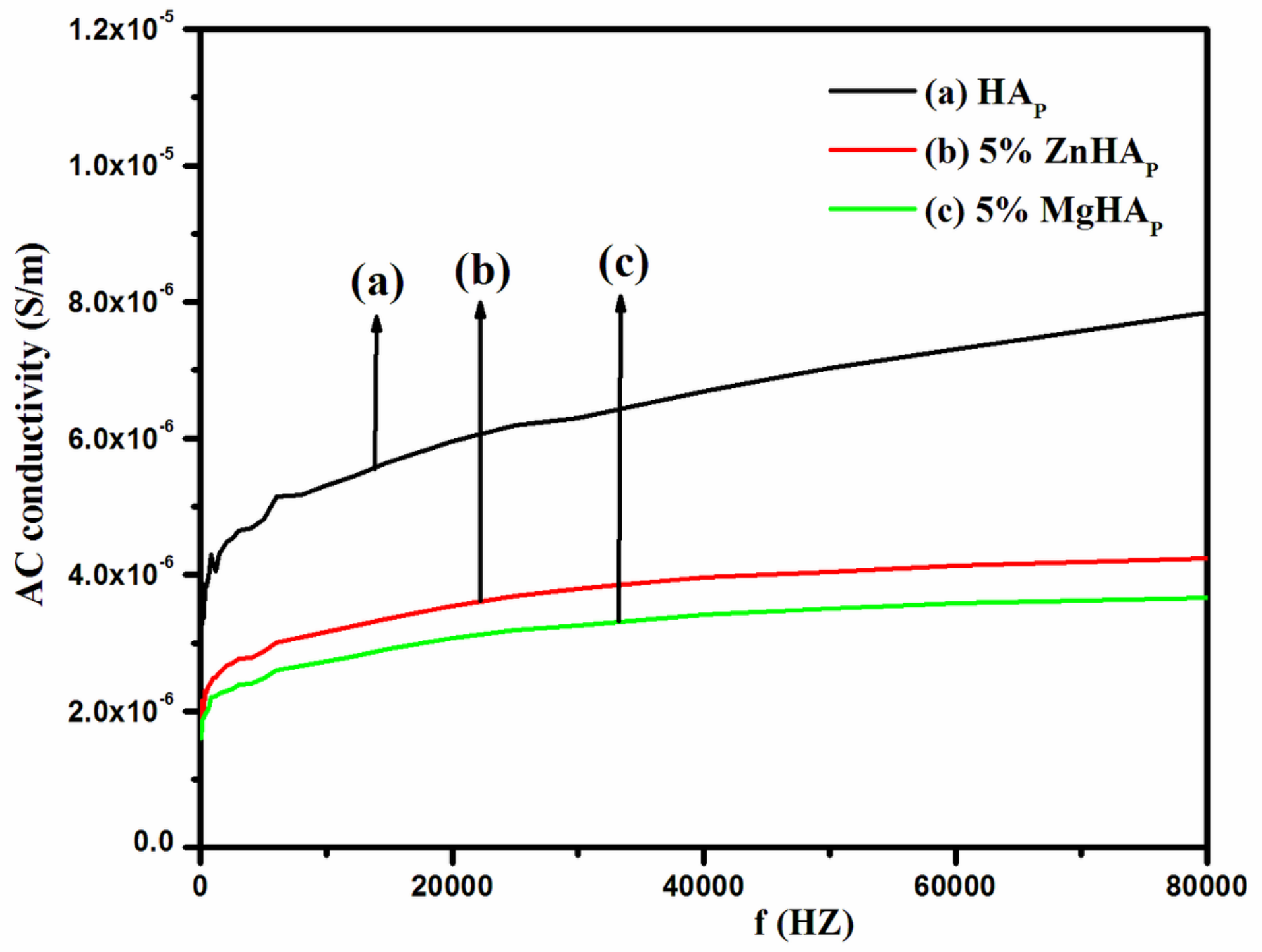

Figure 11

Magnetization Curve of the pure HAP, 5\% ZnHAP, and 5\% MgHAP for as-prepared samples. 


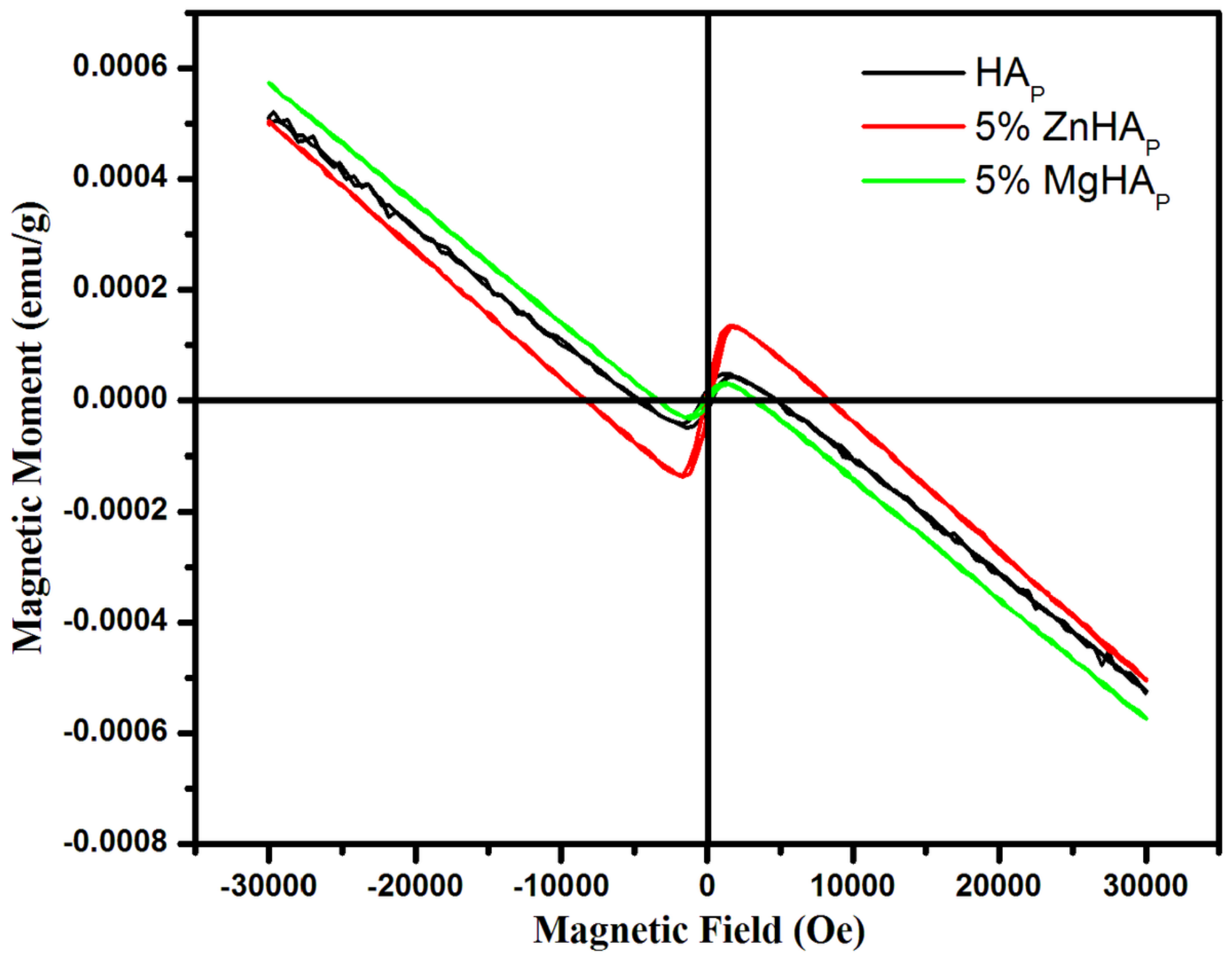

Figure 12

Magnetization Curve of pure HAP, $5 \%$ ZnHAP and $5 \%$ MgHAP annealed at $900^{\circ} \mathrm{C}$. 

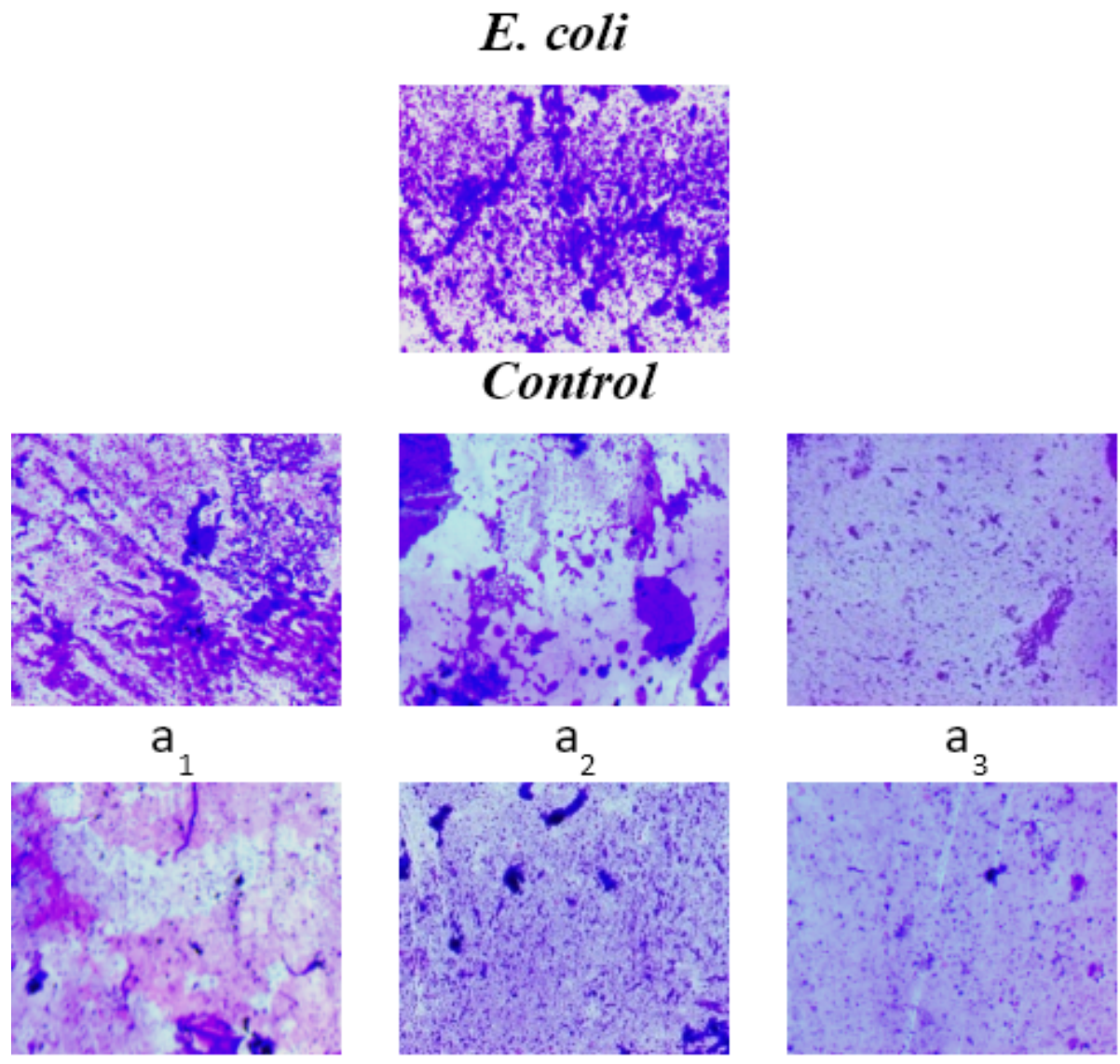

$b_{1}$

$b_{2}$

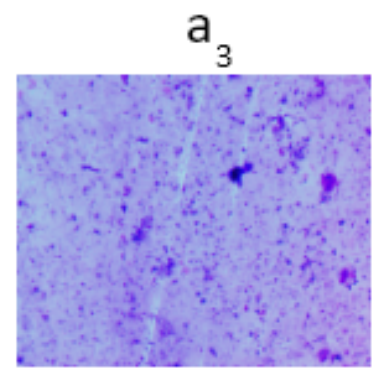

$b_{3}$

Figure 13

Antibiofilm of pure and doped HAP, a 1, a2 and a3 are antibiofilm of 1, 3 and 5\% Zn HAP respectively. And b1, b2 and b3 are antibiofilm of 1, 3 and 5\% Mg HAP respectively. 


\section{S. aureus}

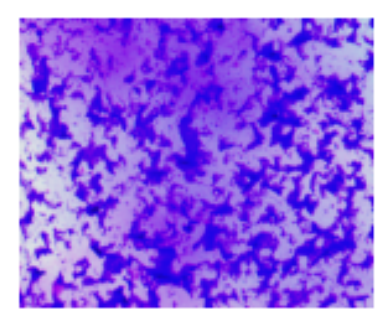

Control
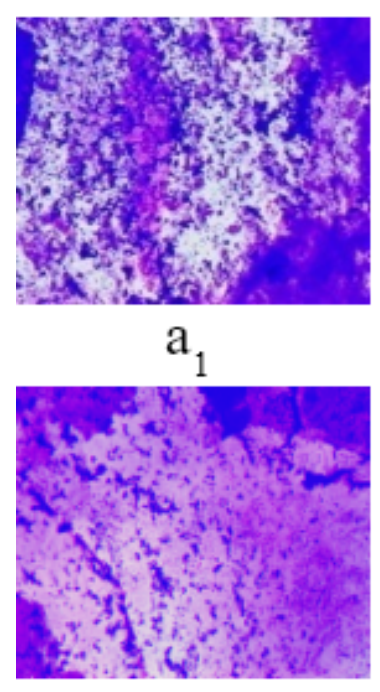

$\mathrm{b}_{1}$

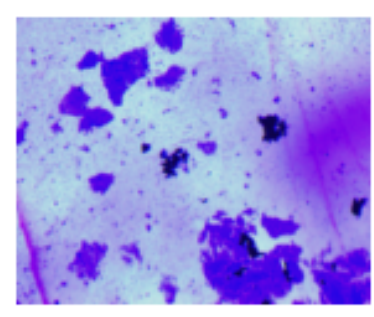

$\mathrm{a}_{2}$

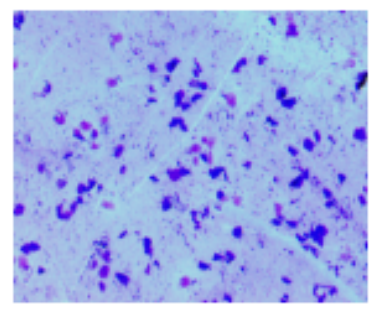

$\mathrm{b}_{2}$

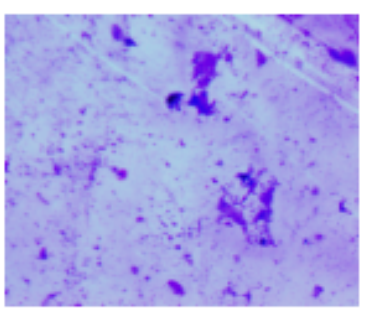

$\mathrm{a}_{3}$

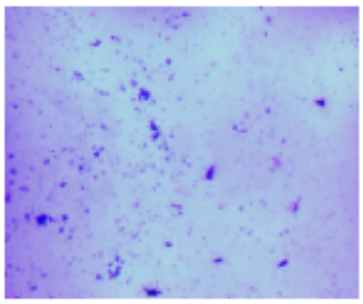

$\mathrm{b}_{3}$

\section{Figure 14}

Antibiofilm of pure and doped HAP, a1, a2 and a3 are antibiofilm of 1, 3 and 5\% Zn HAP respectively. And b1, b2 and b3 are antibiofilm of 1, 3 and 5\% Mg HAP respectively.

\section{Supplementary Files}

This is a list of supplementary files associated with this preprint. Click to download.

- Supplimentery.doc 